\title{
Strophomenidae, Leptostrophiidae, Strophodontidae and Shaleriidae (Brachiopoda, Strophomenida) from the Silurian of Gotland, Sweden
}

\author{
Ole A. Hoel
}

Received: 23 September 2010/Accepted: 1 October 2010/Published online: 13 November 2010

(C) The Author(s) 2010. This article is published with open access at Springerlink.com

\begin{abstract}
Twelve species of Brachiopods are described from the Silurian of Gotland, six furcitellinines and six "strophodontids." One is new-Strophodonta hoburgensis n. sp. The furcitellinines are moderately common and diverse in the lower part of the succession, but the last species disappears in the middle Hemse beds $(\sim$ middle Ludlow). Three genera are represented: Bellimurina, Pentlandina and Katastrophomena, with the species and subspecies $B$. wisgoriensis, $P$. tartana, $P$. loveni, $P$. lewisii lewisii, K. penkillensis and K. antiquata scabrosa. Most of the taxa are confined to low energy environments, but $P$. loveni was evidently specialized for the high energy reef environments of the Högklint Formation. B. wisgoriensis displays environmentally induced morphological variability in developing strong, frilly growth lamellae in high-energy environments. The "strophodontids," although belonging to three different families, share a common morphology consisting of denticles along the hinge line, a semi-circular outline, unequally to finely costellate ornament and, most importantly, a concavo-convex profile with both valves of the same curvature, enclosing a very small body chamber. Two leptostrophiids are generalists, occurring in both highand low-energy environments and with long stratigraphical ranges [Mesoleptostrophia filosa; latest Llandovery through the entire Ludlow. Brachyprion (Brachyprion) semiglobosa; latest Llandovery to latest Wenlock]. The third leptostrophiid (Brachyprion (Erinostrophia) walmstedti) is
\end{abstract}

\section{O. A. Hoel}

Department of Earth Sciences (Palaeobiology Program),

Uppsala University, Norbyvägen 22, 75236 Uppsala, Sweden

Present Address:

O. A. Hoel $(\varangle)$

Herumveien 35, 1430 Ås, Norway

e-mail: ole_a_hoel@yahoo.no short ranged and occurs in low-energy environments in the latest Llandovery. The species belonging to the Strophodontidae (Strophodonta hoburgensis n. sp.) and Shaleriidae [Shaleria (Janiomya) ornatella and S. (Shaleriella) ezerensis] occur only in high-energy environments and have a short range within the late Ludlow.

Keywords Silurian - Llandovery - Wenlock · Ludlow · Strophomenide · Furcitellininae · Leptostrophiidae . Strophodontidae $\cdot$ Shaleriidae

Kurzfassung Zwölf arten Brachiopoden von der Silurium Gotlands sind beschrieben. Sechs Furcitellininen und sechs „Strophodonten“. Eine Gattung ist neu; Strophodonta hoburgensis sp. n. Der Unterfamilie Furcitellininae sind auf Gotland ein gemäßigt häufiger und gering diverser Bestandteil der untere teil der Abfolgen, aber die letzte Art der Unterfamilie verschwindet in den mittleren Hemse Schichten des mittleren Ludloviums. Die drei Gattungen Bellimurina, Pentlandina und Katastrophomena sind mit den folgenden Arten und Unterarten vertreten: B. wisgoriensis, P. tartana, P. loveni, P. lewisii lewisii, K. penkillensis und $K$. antiquata scabrosa. Die meisten Taxa sind auf ein niedrigenergetisches Ablagerungsmilieu beschränkt, wohingegen $P$. loveni offensichtlich auf das hochenergetische Milieu im Bereich der Riffe der Högklint Formation spezialisiert war. B. wisgoriensis weist eine milieuabhängige, morphologische Variabilität auf, die sich in der Entwicklung von rüschenartigen Wachstumslamellen unter hochenergetischen Bedingungen auszeichnet. Die „Strophodonten“, hört zu drei verschiedene Familien zu. Sie teilen eine gemeinsame morphologie die von der volgende bestehen: kleine zähne längs die linie des Hänges, eine semi sirkulares Umriss, ungleichartiger zu feiner costellate Skulptur, und am wichtigsten, eine konkavo-konvexes profil mit 
beiden Schalen mit gleichartig Kurve, der eine sehr kleine Körperkammer umschliesst. Zwei Leptostrophiiden (Mesoleptostrophia filosa und Brachyprion (Brachyprion) semiglobosa) sind generalisten, die im sowohl Hochenergieals Swachenergiemilieuen und durch langer stratigraphisher Intervall auftreten. Der dritten Leptostrophiid (Brachyprion (Erinostrophia) walmstedti) hat eine kürtzere stratigrafisher Auftreten und tret im Swachenergiemilieuen in die spätesten Llandovery auf. Die die zu den Strophodontidae (Strophodonta hoburgensis sp.n.) und Shaleriidae (Shaleria (Janiomya) ornatella und S. (Shaleriella) ezerensis) zuhört treten nur im Hochenergiemilieuen auf und treten durch eine kürzere Interwall innerhalb der spätere Ludlow auf.

Schlüsselwörter Silurium Llandovery · Wenlock · Ludlow · Furcitellininae · Leptostrophiidae · Strophodontidae $\cdot$ Shaleriidae $\cdot$ Schweden

\section{Introduction}

The strophomenide taxa found in the Silurian succession of Gotland, Sweden, are a mix of groups that are typical of the Ordovician and groups that are characteristic of the Devonian faunas. Representative taxa of the former are the Strophomenidae and Leptostrophiidae, while the latter belong to the Strophodontidae and the Shaleriidae. Some of the species described in this article have been relatively well described and figured elsewhere, mainly from the British Isles, but apart from the rather cursory papers of Lindström (1861) and Bassett and Cocks (1974), very few illustrations of Gotland material have been published. The lack of illustrations is somewhat surprising, with respect to the classical status of the area, and the large amount of papers dealing with the island's geology. During this work, it was recognized that many species display quite extensive variation in morphology. I have therefore decided to illustrate each species with a larger number of illustrations than has previously been usual. Hopefully this makes the paper more useful for later studies both of the animals' palaeobiogeography and their palaeobiology.

The Strophomenidae are a predominantly Ordovician group, but a few members of the subfamily Furcitellinae cross the Ordovician-Silurian boundary, and a single genus (Katastrophomena) persists into the Ludlow (Cocks and Rong 2000). The Llandovery furcitellinine taxa of the British Isles were studied by Cocks (1968), who described nine nominal species and a few specimens under open nomenclature, belonging to six genera. From the Wenlock of the Welsh Borderland and South Wales, Bassett (1974) described three furcitellinine species belonging to the genera Pentlandina and Katastrophomena. He also noted that the variation within each species was considerable, and divided two of the species into several subspecies, although making clear that he considered most of the morphological variation to reflect micro-environmental rather than genetic causes.

Members of this subfamily are relatively rare in the Wenlock faunas of the British Isles, and this also is the case on Gotland. The collections in the Swedish Museum of Natural History, Stockholm, and Museum of Evolution, Uppsala, contain only about 300 specimens of furcitellinines, in contrast to over 1,000 specimens of leptaenines (Hoel 2005). The furcitellinines also have a more restricted distribution than the leptaenines; Pentlandina and Bellimurina occur only along the NW coast and on Stora Karlsö, while Katastrophomena has a similar restricted distribution in the lower part of the succession. In the Ludlow Hemse group, specimens are also found further east, but they are mainly confined to low-energy environments within the western marlstone area. The geographical distribution of furcitellinine species is shown in Fig. 1, which also shows the distribution of the main facies. The stratigraphical ranges are shown in Fig. 2.

While the closely related furcitellinines can be morphologically extremely variable both within and between species, several other strophomenide taxa occur in the Gotland succession that belong to three different families, yet share a very similar morphology: This similarity consists of a semicircular shell shape, concavo-convex profile with very narrow body cavity (the opposing valves lie very close to each other along the entire length of the animal), a fairly similar unequally parvicostellate radial ornament (considered to be primitive by Harper and Boucot 1978c, p. 6), usually without any rugation, and development of denticles for articulation along the hinge. On Gotland, species of Brachyprion and Mesoleptostrophia are among the most common and widespread brachiopod taxa. Both genera occur in high- and low-energy environments without displaying much phenotypical variation attributable to environmental influences. On the other hand, the other two fairly similar genera described here (Strophodonta and Shaleria) have a short temporal range on Gotland and are only found in high-energy, shallow water environments.

\section{Geological setting}

The island of Gotland in the Baltic Sea, east of the Swedish mainland, forms a small, exposed part of the much larger area of Palaeozoic rocks comprising the bedrock of the southern-central region of the Baltic Sea, the East Baltic states and parts of Russia and Belarus. The Silurian succession on Gotland spans a time interval from the latest Llandovery to the late Ludlow. During that time Gotland was situated near the southern margin of Baltica, about $15^{\circ}$ 
Fig. 1 Map of Gotland showing main sedimentary facies and distribution of the species described herein. The distribution of

Mesoleptostrophia filosa covers the entire island, and is therefore not plotted

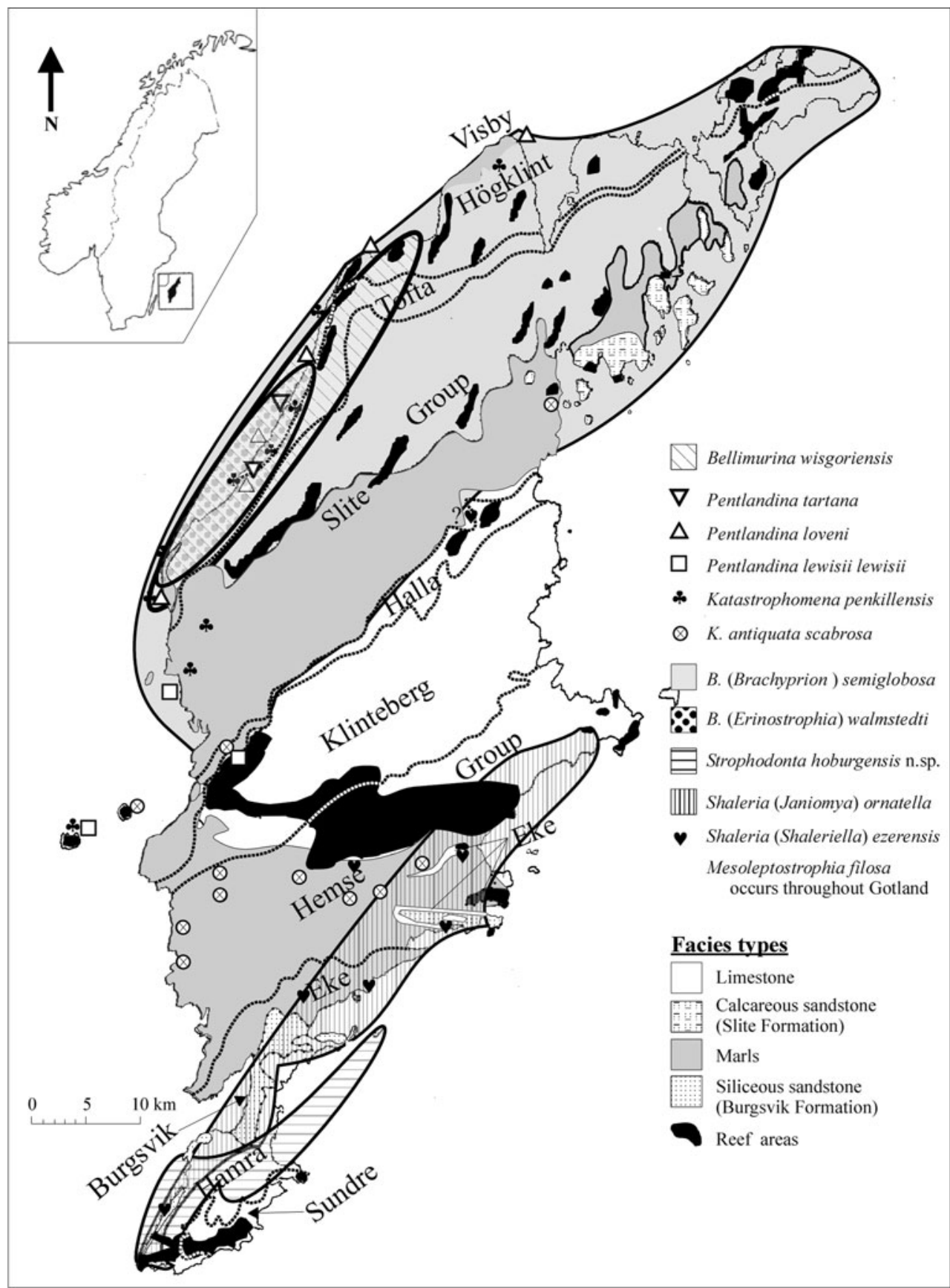

south of the palaeoequator (Torsvik et al. 1996). Sedimentation occurred on a shallow pericontinental ramp, and the rocks consist mostly of mudstones, marlstones and limestones, with some relatively minor units of sandstones. Extensive reef bodies are also present at several levels of the stratigraphical record. The rock units dip very gently $\left(\sim 1^{\circ}-2^{\circ}\right)$ towards the SE. At the time of sedimentation, water depth was generally greater in the SW, so that the succession is most complete in the west with about $500 \mathrm{~m}$ of sedimentary succession in the SW region near Hamra, whereas there are increasingly large reef tracts, unconformities and other signs of near-shore influences in the east. The stratigraphy and depositional environments of the succession exposed on Gotland have been studied in numerous papers, and the most useful overviews of the geology are those of Hede (1921, 1960), Munthe et al. (1925), Manten (1971), Laufeld (1974), Laufeld and Bassett (1981), Bassett (1985) and Samtleben et al. (1996).

\section{Systematic palaeontology}

Abbreviations and repositories: GSM-Institute of Geological Sciences, London; LMNH-Latvian Museum of 
Fig. 2 Stratigraphical ranges on Gotland of the species described herein. The occurrence of Shaleria (Shaleriella) ezerensis in the Slite group may be erroneous, as it is based only on the locality list in Harper and Boucot 1978b, and no specimen is figured by them from this level

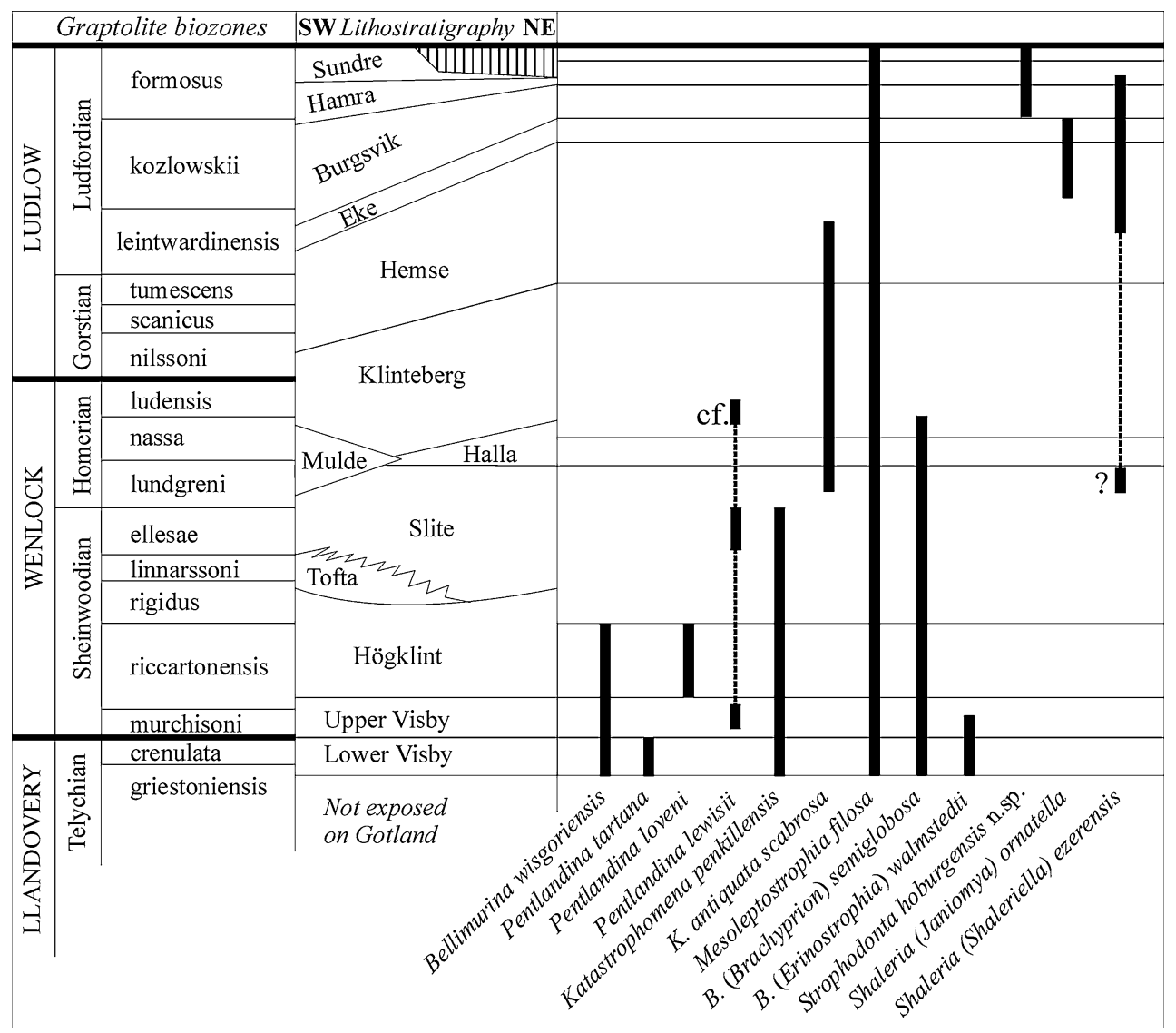

Natural History, Riga; NMING-National Museum of Ireland, Dublin; PMU-Museum of Evolution, Uppsala University, Sweden; SGU-Geological Survey of Sweden, Uppsala; NRM-Swedish Museum of Natural History, Stockholm; USNM-US National Museum of Natural History, Washington.

The synonymy lists of some species would be very long, and have therefore been reduced by including only the original reference and those pertaining to descriptions of Scandinavian material before 1977. For more complete lists see Bassett's monographs (1971-1977).

\section{Class Strophomenata Williams and others, 1996 Order Strophomenida Öpik, 1934 \\ Superfamily Strophomenoidea King, 1846 \\ Family Strophomenidae King, 1846}

Classification of the strophomenides has a long history of discussion and conflicting opinions, and it possibly is the most taxonomically over-split major brachiopod group. The main differentiation has been made between the "normal" strophomenides with a "conventional" tooth and socket articulation and the "strophodontids" with additional denticulate structures along the hinge line. Harper and Boucot (1978a, b, c, pp. 60-61) recognized ten families within the "Strophodontacea" based on ornament, convexity, shape of ventral muscle field, socket plates and brace plates. Their tabulation implies that their main defining familial character was the shape of the ventral muscle field. In contrast, Rong and Cocks (1994) used the shape of the dorsal cardinalia as their key familial character for the non-denticulate families. They defined four types, each of which supposedly characterizes a family: Type A (Strophomenidae) has a prominent notothyrial platform, the cardinal process lobes can be fused proximally and the socket ridges are curved postero-laterally, which Rong and Cocks claim to be unique for this group. Type B (Rafinesquinidae) has long, discrete cardinal process lobes and straight socket ridges. Type C (Glyptomenidae, Foliomenidae, ?Leptaenoideidae) has socket ridges fused directly to the sides of the small cardinal process lobes. Type D (Christianiidae) has low, fused cardinal process lobes and the socket ridges are developed as plates overhanging the valve floor. These authors regard the morphology of the cardinalia as being very conservative and thus valid as readily defining characters for each family. It is surprising therefore to see cardinalia clearly similar to their type A rather than type $\mathrm{C}$, complete with curved socket ridges in Glyptomena, the presumably most typical Glyptomenid (see Cocks and Rong 2000, Fig. 156). In fact, most of the genera assigned to Glyptomenidae figured by 
Cocks and Rong (2000, Figs. 156-159) have cardinalia and dorsal muscle fields very similar to those assigned to Strophomenidae (Cocks and Rong 2000, Figs. 135-145). Their types $\mathrm{A}$ and $\mathrm{C}$ differ in reality only in the relative size of the cardinal process lobes. Since both the proximal ends of the cardinal process lobes and the proximal ends of the socket ridges are contiguous with the notothyrial platform in both types, it is somewhat a matter of definition as to whether the socket ridge actually contacts the cardinal process lobe or not. The cardinalia of Leptaenoidea (Hoel 2007) seem to be similar to the Type $C$ in having socket ridges in contact with the cardinal process lobes through all their height, but the notothyrial platform is well developed, with a strong median ridge reaching far forward in the mantle cavity, as in Type A. Most other characters of Leptaenoidea are also consistent with a close relationship with the subfamily Furcitellinae within the Strophomenidae (Hoel 2007). For the denticulate families, Rong and Cocks (1994) followed Harper and Boucot (1978a, b, c) quite closely, although reducing the number of families to seven. In these groups, they defined three types of cardinalia, but did not attach much confidence to them as defining characters. They considered instead the shape of the ventral muscle field to be a conservative feature, although they did not discuss why the ventral muscle field should be a more conservative structure in the "strophodonts" than in the non-denticulate stocks. However, they argued that the narrow space between the valves hindered evolutionary development of the cardinalia. Supposedly this is the reason why the cardinal process was such a conservative feature in most strophomenata, but it does not explain why even the denticulate families in fact show dramatic evolution of the cardinalia (see, e.g., Williams 1953), especially because many of these brachiopods did have extremely narrow space between the valves. The work of Rong and Cocks (1994) (and by extension that of Cocks and Rong 2000) can be said to have been a step forward in stating more clearly what characters the classification was based on, but the characters used in the definitions are probably still too few and too variable: A comprehensive cladistic analysis of the Strophomenida is required in order to elucidate many of the relationships that would lead to a more compatible classification, but is beyond the scope of the present paper.

\section{Subfamily Furcitellinae Williams, 1965 Genus Bellimurina Cooper, 1956}

Type species: By original designation; Leptaena charlottae Winchell \& Schuchert, 1892, p. 288.

Remarks: Cocks and Rong (2000) differentiated between two subgenera, Bellimurina (Bellimurina) from the Caradoc of North America and B. (Cyphomenoidea) from the late
Llandovery of Europe and North America. I agree that the morphology is so similar that a close phylogenetic relationship is probable, although the temporal distribution of the genus thereby becomes discontinuous. The difference between the two subgenera is defined such that $B$. (Bellimurina) has continuous dorsal transmuscle ridges and a low peripheral rim in the dorsal valve, whereas $B$. (Cyphomenoidea) has vestigial dorsal transmuscle ridges and a high peripheral rim. In my opinion these small morphological differences between the subgenera make splitting within the genus unnecessary. A similar degree of variation is found even within populations of B. visgoriensis described below from the lower Visby Formation of Gotland. The variation there seems to correlate with growth; although some large specimens lack the rim (see Fig. 3Z), the specimens with the highest peripheral rim are usually also the largest and most gerontic, with the most elevated muscle scars (see Fig. 3P), where any transmuscle ridges are effaced. It thus appears that these two distinguishing characters are dependent only on the ontogenetic development of the specimen in question. The separation of Bellimurina into subgenera is therefore not followed in this paper.

Bellimurina wisgoriensis (Lamont and Gilbert, 1945) (Fig. 3)

v.1916 Rafinesquina(?) sp.-Holtedahl: 31, pl. 3, Fig. 6

$\mathrm{v} * 1945$ Leptaena wisgoriensis-Lamont \& Gilbert: 660, pl. 3, Figs. 10-14

v.1951 Leptaena wisgoriensis Lamont \& Gilbert.Williams: 119

v.1968 Cyphomena (Cyphomenoidea) wisgoriensis (Lamont \& Gilbert).-Cocks: 316, pl. 12, Figs. 9, 10, 11, 12

v.1968 Bellimurina sp.-Cocks: 321, pl. 14, Figs. 9-10

v.1978 Cyphomena (Cyphomenoidea) wisgoriensis (Lamont \& Gilbert).-Cocks: 119

v.1982 Cyphomenoidea wisgoriensis (Lamont \& Gilbert)._Thomsen \& Baarli: pl. 3, Figs. 9, 11, 12

v.1995 Cyphomenoidea wisgoriensis (Lamont \& Gilbert).-Baarli: 40, pl. 13, Figs. 12-23

Material: About 50 specimens; conjoined valves, ventral and dorsal interiors from the lower and upper Visby Formation and the Högklint Formation.

Description: Shell semi-rectangular to transverse, about $60 \%$ as long as wide, with the maximum width mostly anterior to the hinge line at about mid length. Ventral valve more or less evenly convex, with the dorsal valve flat to slightly concave and with a weak, short geniculation in the anterior third. 
Ventral beak prominent, extending beyond the hinge line and bearing an open, permesothyrid foramen. Pseudodeltidium relatively large, occupying about $10 \%$ of the hinge width and about $75 \%$ of interarea height. The height of the ventral interarea is slightly less than $10 \%$ of the hinge width. Dorsal interarea very low, notothyrium as wide as the pseudodeltidium, and with a prominent chilidium covering the proximal part of the cardinal process lobes.

The shell has a characteristic sculpture of low, sharp rugae deflected forwards where they are crossed by the costae. The costellae do not make any impression on the rugae. The concentric ornamentation also involves growth interruptions where the mantle has retracted before continuing growth below the former commisure line. This interrupted pattern is repeated at shorter and shorter intervals as the animal approaches full size and this results in a frilly valve surface. Most specimens show two or three more pronounced growth lines where the growth of the valves ceased briefly.

Ventral interior: Delthyrial cavity deep below the pseudodeltidium, without any visible callist. Teeth widely divergent, ridge-like to subtriangular in dorsal view, with numerous small ridges perpendicular to the hinge line along the posterior side, and supported by wide dental plates, which are continuous with the muscle bounding ridges at their frontal edge. The muscle field is round to diamond-shaped; the posterior part is slightly depressed, but most of the field is elevated well above the valve floor, surrounded by high muscle bounding ridges that overhang the valve floor and almost meet anteromedially. The adductor scars are relatively small, set in the extreme posterior of the delthyrial cavity, extending forwards as far as half of the muscle field length. Diductor scars triangular and elongated, with width about half the height of the muscle bounding ridge. The muscle scars are separated by a thick, rounded median ridge, which increases in height forwards and in some specimens continues well in front of the muscle field, and is raised as a high, cutoff knob at the frontal end of the muscle field (Fig. 3R, V). The extramuscular area close to the muscle field is covered in very small pustules less than $0.05 \mathrm{~mm}$ in diameter, but further frontally the pustules disappear and the surface is almost smooth. The vascula media extend from the anteromedial end of the muscle field as two quite wide troughs with slightly elevated edges. The troughs then bifurcate two or three times as they approach the valve margin, where they occupy only the anterior half of the commisure line.

Dorsal interior: The disc is surrounded by a bounding ridge, which can be quite high (Fig. 3P), or by several successive low bounding ridges coinciding with the major halts in shell growth seen on the outside of the valve. The
Fig. 3 Bellimurina wisgoriensis (Lamont \& Gilbert, 1945). Scale bar $1 \mathrm{~cm}$. A-C NRM Br 35380, conjoined valves with slight geniculation, ventral, dorsal and lateral views; lower Visby Formation, Norderstrand, Visby; D-E NRM Br 123656, conjoined valves, dorsal, posterior and ventral views; Galgberget, Visby; F-H NRM Br 138064, small dorsal valve, posterior, dorsal and ventral views; Ireviken 2, Stenkyrka; I, M NRM Br 123693, dorsal valve, posterior and dorsal views; Visby, old collection; J-L, N NRM Br 123692, dorsal valve, frontal, dorsal, posterior and ventral views; Visby, old collection; O-Q NRM Br 35376, dorsal interior, ventral, posterior and lateral views; upper Visby Formation at Blåhäll, Tofta parish; R-S, V NRM Br 123649; Ventral interior in views perpendicular to the commisure, the interarea and parallel to the interarea; lower Visby Formation, Norderstrand; T NRM Br 123689, small dorsal valve interior; Galgberget, Visby; U NRM Br35381, dorsal interior view; lower Visby Formation, Norderstrand; W-Y PMU G1058, conjoined valves with frilly lamellar growth; Visby Formation, unknown locality; Z NRM Br 123650, dorsal interior with exterior sculpture highly visible; lower Visby Formation, Norderstrand; Aa-Ab PMU G1059, dorsal interior, ventral and posterior views; Visby Formation, unknown locality

cardinalia are stout, supported on a short, elevated notothyrial platform. Cardinal processes are relatively long and tubular, diverging about $15-30^{\circ}$; their muscle attachment facets are oval and posteriorly directed, their proximal parts covered by the small chilidium. The sockets are deep and trough-like, with their open end angled posteriorly. Socket plates are quite thick, curving slightly, fused posteriorly with the notothyrial platform, and diverging at about $120^{\circ}$. Muscle field is elevated, bisected longitudinally by a wide, convex ridge, which is fused to the notothyrial platform posteriorly and is forked anteriorly. Posterior end of each adductor scar is a deep, crescentshaped pit bounded posteriorly by the notothyrial platform, while the scars themselves are set on the broad transmuscle septa, which diverge anterolaterally at about $45^{\circ}$. Each transmuscle septum is composed by two parallel subsepta; the lateral subseptum is well elevated above the floor of the valve, while the medial subseptum is slightly lower and continues forwards as a narrow curved ridge enveloping the frontal scars, but they do not meet medially. The extramuscular area is covered with extremely small ridges and pustules, and the external ornament is clearly visible on the inside. There are no visible vascular traces in the dorsal valve.

Remarks: Most of the specimens from the lower Visby Formation in the NRM museum collections previously identified as Pentlandina belong to B. wisgoriensis. This species can be distinguished easily from the specimens of Pentlandina tartana (see below), which co-occurs at Norderstrand, Visby; B. wisgoriensis is usually much larger, and it has a strong zig-zag rugae pattern, frilly lamellose growth lines, and usually more pronounced growth ridges; the specimens also lack the fold and sulcus of Pentlandina. In the Högklint Formation, the specimens 


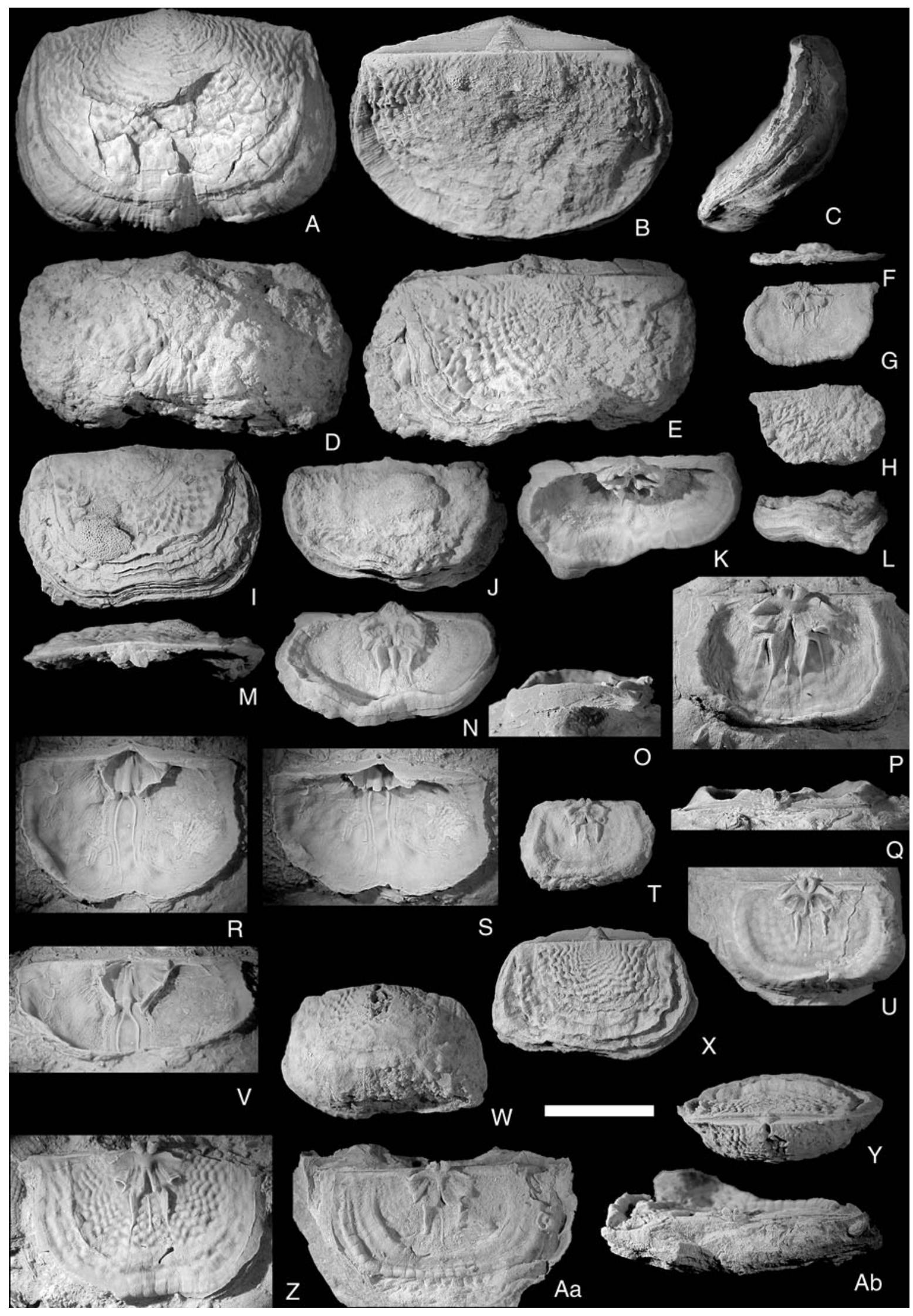


are generally larger and have a stronger sculpture, with more frequent and distinct growth reversals of the anterior margin, resulting in more frilly appearance.

Distribution: B. wisgoriensis occurs in the lower and upper units of the Visby Formation and in the Högklint Formation, from Gnisvärd in the SW to Irevik in the NE.

Norwegian specimens belonging to this species were described by Baarli (1995) from the top of the Rytteråker Formation and base of the Vik Formation. These are of middle Telychian $\left(\mathrm{C}_{4}\right)$ age (Worsley et al. 1983), and thus slightly older than the British specimens described by Cocks (1968), which is of $C_{5}$ age. A few specimens were also found by me in the lower part of the Braksøya Formation (lowermost Wenlock) on Storøya, Ringerike, Norway. These specimens display almost only the concentric ornamentation, and no radial costellae, which makes the shell seem incredibly wrinkled.

In the British Isles it is recorded from the latest Llandovery of Worcestershire, but may be present also in Shropshire (Cocks 1968, p. 317).

Genus Pentlandina Bancroft, 1949

Type species: Strophomena (P.) tartana Bancroft, 1949, p. 13; OD.

\section{Pentlandina tartana Bancroft, 1949 (Fig. 4)}

$\begin{array}{ll}\text { v.1866 } & \begin{array}{l}\text { Strophomena antiquata (J. de C. Sower- } \\ \text { by).-Davidson: 17, pl. 2, Figs. 21-23 }\end{array} \\ \text { v.1871(part) } & \begin{array}{l}\text { Strophomena antiquata (J. de C. Sower- } \\ \text { by).-Davidson: 299, pl. 44, Figs. 7-9 only }\end{array} \\ \text { v*1949(part) } & \begin{array}{l}\text { Strophomena (Pentlandina) tartana [Lamont } \\ \text { MS].—Bancroft: 13, non pl. 1, Fig. 10 }\end{array} \\ \text { v.1968 } & \begin{array}{l}\text { Pentlandina tartana Bancroft.—Cocks: } \\ \text { 289, pl. 1, Figs. 1-6 }\end{array} \\ \text { v.1974 } & \text { Pentlandina sp.-Bassett \& Cocks: } 14\end{array}$

Material: Eighteen specimens, all conjoined valves from the lower Visby Formation just north of Visby. All specimens were probably found loose in beach gravel and are quite strongly worn, almost obliterating the outer surface in some specimens.

Description: Outline semicircular to transversely subrectangular, usually about $60 \%$ as long as wide. Ventral valve initially convex at the umbo, but after the first major growth line (at around 25-30\% of adult length), a deep sulcus develops in the ventral valve, with a corresponding fold in the dorsal valve. In some specimens this folding is so strong that the anterior commisure is vertical on both sides of the median line, but usually the commisure has an angle to the horizontal of around $45^{\circ}$. Ventral umbo low; sometimes a very small, open apical foramen is visible. Ventral interarea relatively high, delthyrial angle $80^{\circ}$. Pseudodeltidium small, only half as high as the width of the interarea; chilidium of equal size as the pseudodeltidium, both narrow, occupying about $1 / 8$ of the length of the hinge line. Radial sculpture parvicostellate, main costellae thin, with 8-10 smaller fila in the interspaces. Concentric sculpture consists of very small growth lines, sometimes produced into small rugae, which are deflected into zig-zags when crossing the costellae. Most specimens also have 2-3 growth ridges, which are mostly developed near the shell margin.

Remarks: This species differs from $P$. lewisii (see below) in having a small pseudodeltidium, covering only the apical part of a wide delthyrium (in $P$. lewisii, the delthyrium is narrower and the pseudodeltidium covers the entire height of it), less accentuated costellae, smaller size, and much stronger development of the fold and sulcus.

Distribution: On Gotland, P. tartana is only known from the lower Visby Formation (latest Telychian) immediately north of Visby.

In the British Isles, it is known from the Pentland Hills, Scotland, and possibly from the Tortworth Inlier, Welsh Borderland; both occurrences are of latest Telychian age.

A somewhat similar species is present in the Ningqiang Formation (late Telychian) of north Sichuan, China (see Bassett and Rong 2002, p. 134, Fig. 92B, C). In that paper, the figured specimen is identified as $P$. cf. lewisii (Davidson), but apart from having the same geological age as $P$. tartana, it also seems to have a similar tall fold and sulcus, and the same strong zig-zag pattern in the concentric ornament as the latter species.

\section{Pentlandina loveni (de Verneuil, 1848) (Fig. 5A-T)}

$\mathrm{v}^{*} 1848$ Leptaena loveni-de Verneuil: 339, pl. 4, Fig. 5 v.1861 Strophomena loveni (de Verneuil).—Lindström: 371

v.1968 Pentlandina loveni (de Verneuil).-Cocks: 289

v.1974 Pentlandina loveni (de Verneuil).—Bassett \& Cocks: 14, pl. 2, Figs. 4-6

Type material: Lectotype-University of Orsay D653, the complete shell figured by de Verneuil on his pl. 2, Fig. 5a; assigned and refigured by Bassett and Cocks (1974, pl. 2, Fig. 5a-c), who also figured the two syntypes of de Verneuil (1848, pl. 4, Fig. 5b, c (D652), and Fig. 5d (D654)).

Description: Shell small, length about $8 \mathrm{~mm}$, rarely up to $15 \mathrm{~mm}$. Outline usually rounded square to almost circular, but is often irregular. The widest point is usually 


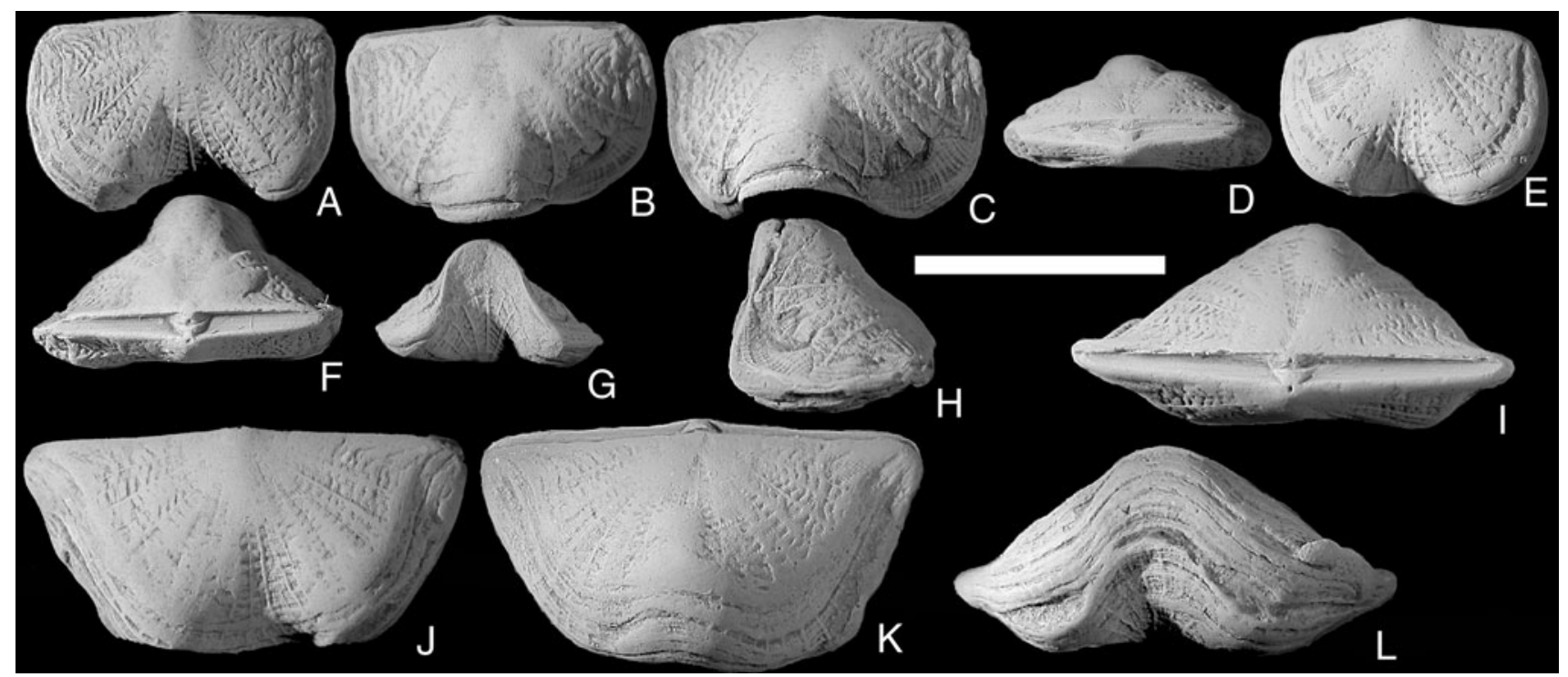

Fig. 4 Pentlandina tartana Bancroft, 1949; Conjoined valves, lower Visby Formation, Norderstrand, Visby. Scale bar $1 \mathrm{~cm}$. A-C, F-H NRM Br 102553; ventral, dorsal, anterodorsal, posterior, anterior and

at about $30 \%$ of final length, but can also be at the hinge width. The profile is concavo-convex to biconvex, with a deep, rounded ventral valve and a flat to convex dorsal valve, often with a ventrally directed furrow followed immediately by a sharp dorsal geniculation in the anteromedial part of the dorsal valve. Frontally, there is usually a very strong fold and sulcus developed, but in some specimens, this structure is not developed at all. Ventral beak is erect, with an open apical foramen. Dorsal beak inconspicuous, but visible as a small knob. Ventral interarea wide, with clear horizontal growth lines, its triangular shape distorted where the shell developed growth ridges; Pseudodeltidium strongly vaulted and high, reaching almost to the hinge line, relatively wide, occupying between $1 / 3$ and $1 / 5$ of hinge line width. Dorsal interarea much narrower than the ventral area, of subequal width out to the lateral margins of the hinge line; chilidium low but convex, relatively narrow, occupying about $1 / 6$ to $1 / 10$ of hinge width, covering most of the cardinal process lobes, but in-folded between them. Concentric sculpture near the apex of both valves comprises small growth lines, in the more distal part of the shells there are usually strong, zigzag shaped rugae; periodical mantle retractions resulted in several growth ridges in many specimens, but they are usually not as strong, nor as numerous as in Bellimurina visgoriensis (see above). Radial sculpture consists of very thin costellae which interrupt the rugae; in the interspaces there are $4-5$ thin fila.

Ventral interior: Delthyrial cavity deep, roofed over by the pseudodeltidium. Teeth strong, triangular, supported by strong dental plates, which blend seamlessly into the lateral views; D-E NRM Br 48921; posterior and ventral views; I-L NRM Br 123648; posterior, ventral, dorsal and anterior views

muscle bounding ridges. Muscle field triangular, in some specimens rectangular, elevated above the valve floor, strongly so in gerontic specimens. Adductor and diductor scars of equal width, each muscle occupying $20 \%$ of the muscle area width; the anterior $20 \%$ is occupied by a low, wide median ridge, which separates the right and left adductors. The anterior end of this ridge is elevated into a knob, then it drops vertically to the valve floor and continues a short distance anteriorly, bounded on both sides by a vascular trace, before blending into the valve floor at about mid-length of the valve. The valve floor is covered by very small taleolae arranged radially.

Dorsal interior: Even in rather flat valves, the interior surface is bowl-shaped and relatively deep. A bounding ridge around the disc is often developed, making the interior relatively more spacious than in most strophomenides. Cardinalia elevated on a strong, anchor-shaped notothyrial platform. Cardinal process lobes strong and elevated, muscle attachment areas directed posteriorly, but in some specimens they point up to $30^{\circ}$ laterally as well. Sockets deep and trough-like, bounded anteriorly by strong socket ridges growing anterolaterally with an angle of $15-20^{\circ}$ to the hinge line. The adductor muscle scars are rounded and deeply impressed posteriorly and divided by the anterior extension of the notothyrial platform, which bifurcates at half the length of the muscle field, producing a deep median trench. The anteromedian scars are supported by this bifurcated median ridge, while the posterolateral muscle scars are supported by blade-like extensions of the muscle field, which overhang the valve floor. From the anterior ends of the anteromedian scars, paired ridges develop, 


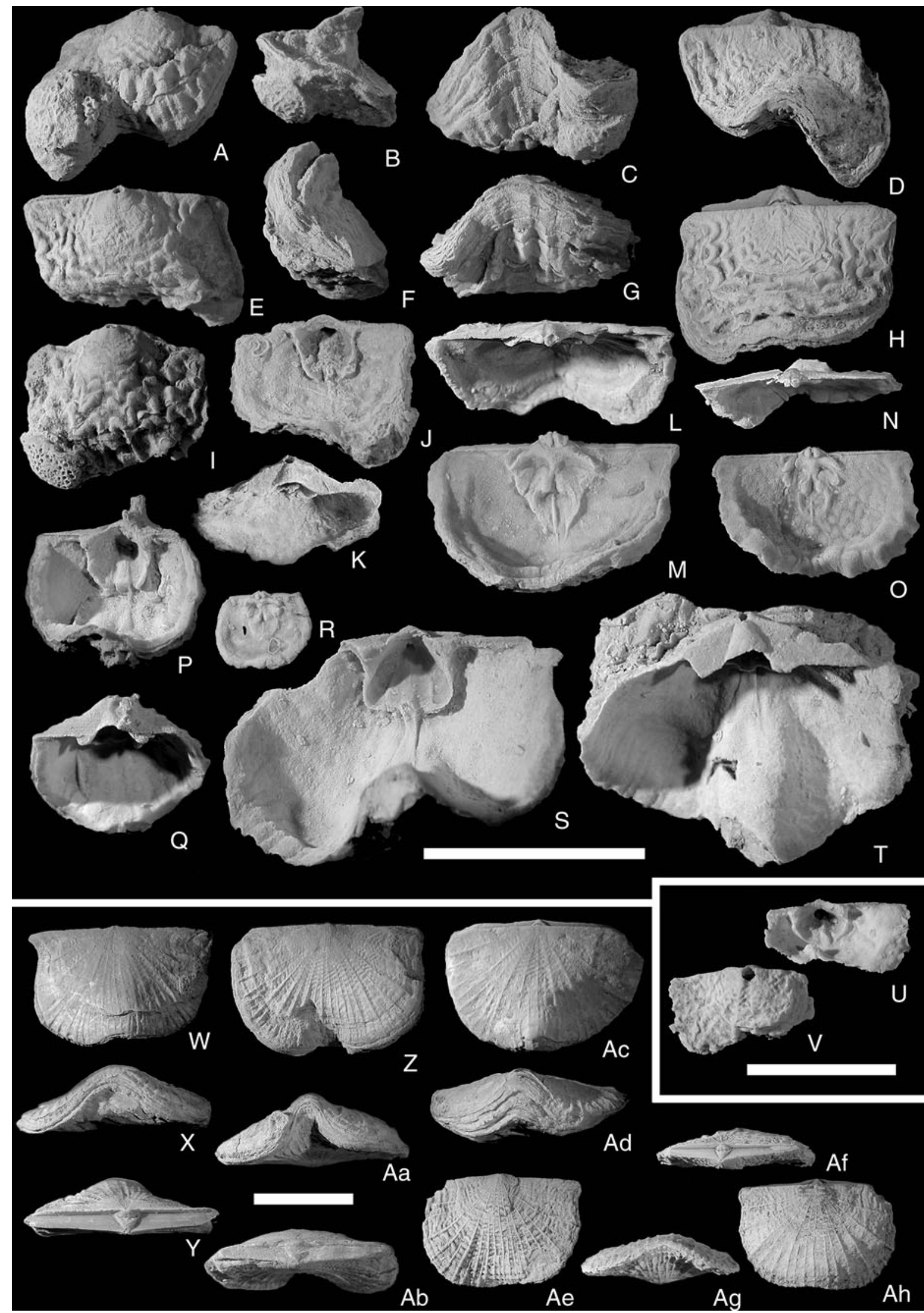


4 Fig. 5 A-T Pentlandina loveni (de Verneuil, 1848); all from the Högklint Formation, note open apical foramina and irregular shape. Scale bar $1 \mathrm{~cm}$; A-D NRM Br 35445, unknown locality; ventral, lateral, dorsal and frontal views; E-H NRM Br 35442, unknown locality; ventral, lateral, frontal and dorsal views; I-K NRM $\mathrm{Br}$ 123673; ventral valve, exterior, interior and posterior views; $\mathbf{L}$, M NRM Br 123676, unknown locality; dorsal valve, posterior and interior views; N, O NRM Br 123675, unknown locality; dorsal valve, interior and posterior views; P, Q NRM Br 123685, Galgbacken, Visby; small, globular ventral valve, exterior, interior and posterior views; R PMU G1062, Lickershamn, Stenkyrka; very small dorsal valve with a larval shell attached to its inner surface; $\mathbf{S}$, T NRM Br 123686, Galgbacken, Visby; large ventral valve with strong fold, interior, posterior and lateral views. U-Af Pentlandina lewisii lewisii (Davidson, 1847); conjoined valves. Scale bar $1 \mathrm{~cm}$. U-W NRM Br 102614, Slite group, Västergarn, Sanda; dorsal, frontal and posterior views; X-Z NRM Br 102616, Slite Group, Västergarn, Sanda; ventral, frontal and posterior views; Aa, Ab NRM Br 35658, upper Visby Formation, Gnisvärd, Tofta; dorsal and frontal views; Ac-Af: NRM Br 123532, Slite Group, Valbytte, Sanda; posterior, frontal, dorsal and ventral views. Ag-Ah Pentlandina cf. loveni (de Verneuil, 1848); NRM Br 138066, incomplete ventral valve with large foramen, Klinteberg Formation, Hunninge 1, Klinte; exterior and interior views

which swing anteromedially to enclose the anterior scars, but do not merge medially. A thin median septum originates within the trench of the bifurcated median ridge and continues forwards between the paired ridges to about $66 \%$ of the valve length, then blends into the valve floor. No clear vascular traces are present, but the valve floor is covered in very small taleolae arranged radially, as in the ventral valve. In young specimens, the exterior sculpture is visible on the inside of the valves, but is obliterated by secondary shell thickening in gerontic individuals.

Remarks: Small specimens of $P$. loveni can be difficult to distinguish from $B$. visgoriensis, but differ by having more anteriorly directed socket ridges, usually more erect cardinal process lobes, and the ridges on both sides of the anterior scars enclose the scars rather than expand forwards as in B. visgoriensis. On the exterior, the two species have similar ornaments, but the strong growth ridges of $B$. visgoriensis are usually not found in small specimens of $P$. loveni.

Specimens of this species from the Högklint Formation are commonly markedly asymmetrical. Some groups of shells occur in tight clusters, each apparently attached to other shells of the same species (e.g., NRM Br 35395, unfigured). The limited space for growth results in the asymmetrical shape. Such gregarious behavior is well known in living brachiopods. Studies on modern faunas have revealed that the orientation of individuals in crowded and clustered populations are quite random, and individuals in the populations observed show no reorientation in response to currents. In this case, stability seems to be of greater importance in determining orientation than the direction of water flow (Richardson 1997, p. 451). For Pentlandina loveni, this may suggest a habitat of current-swept hard ground.

Distribution: $P$. loveni is known with certainty only from Gotland, where it occurs in the early Wenlock Högklint Formation and coeval beds assigned to the middle Slite group on Fårö.

\section{Pentlandina cf. lewisii (Davidson, 1847) (Fig. 5U, V)}

Remarks: Two small specimens were found in the Slite group at Slite (NRM Br 136067; not figured) and NRM Br 138066 (Fig. 5U, V) from the Klinteberg Formation at Klinteberg. They are similar to $P$. loveni in having a large open apical foramen and also have a ventral muscle field quite similar to small specimens of the latter species (e.g., Fig. 5P). Their shell ornamentation is more similar to that of $P$. lewisii lewisii (e.g., Fig. 5Ae), but the ventral muscle field of that species is quite different, as can be seen in Bassett (1974, pl. 25, Figs. 14, 15). In my view, these specimens are evolutionarily intermediate between the two species (at least the one from Klinteberg), possibly closer to $P$. lewisii (on stratigraphic criteria), but lived in higher energy environments than the other known specimens and retained pedicular attachment into adulthood.

Pentlandina lewisii lewisii (Davidson, 1847) (Fig. 5W-Ah)

$\mathrm{v} * 1847$ Leptaena lewisii-Davidson: 59, pl. 12, FigS. 22-24

v.1848(part) Leptaena antiquata (J. de C. Sowerby).Davidson: 319 pars, pl. 3, Fig. 11 right hand fig., non left hand fig., non J. de C. Sowerby in Murchison, 1839

v.1871(part) Strophomena antiquata (J. de C. Sowerby).—Davidson: 299, pl. 44, Figs. 3, 3a, non Figs. 2, 4-13, 21, 22, non J. de C. Sowerby in Murchison, 1839

v.1916 Strophomena loveni (de Verneuil).Holtedahl: 60, pl. 13, Fig. 5

v.1949 Strophomena (Pentlandina) aff. tartana [Lamont MS].-Bancroft: p. 13

v.1968 ?Pentlandina lewisii (Davidson).—Cocks: 289 [reference to species only, questionably assigned to Pentlandina]

v.1974 Pentlandina sp.-Bassett \& Cocks: 14 [reference to specimens found on Gotland with tentative assignment to species]

v.1974 Pentlandina lewisii (Davidson).-Bassett: 101, pl. 25, Figs. 10-16, pl. 26, Figs. 1-3

Material: 28 conjoined valves from the Slite group, one conjoined specimen from the upper Visby Formation. 
Remarks: This species was described by Bassett (1974), and the Gotland specimens do not exhibit any marked differences from the British material, except in having a ventral interarea that has more even width along the whole hinge line and a less frilly appearance of the costellae where they are crossed by the concentric growth lines.

Distribution: On Gotland, the species is known from a single specimen in the upper Visby Formation at Gnisvärd, and more commonly in the western part of the middle Slite group (late Sheinwood) around Västergarn and on Stora Karlsö. This region had a rather low-energy sedimentary environment.

In Norway only two specimens are known (Holtedahl 1916, pl. 10, Fig. 9; pl. 13, Fig. 5) from the basal part of the Malmöya Formation (middle Wenlock, coeval with the base of the Slite group on Gotland). In the specimen PMO L-139 (Holtedahl 1916, pl. 13, Fig. 5), the ornamentation is more or less identical to that of the holotype of $P$. lewisii plakodis Bassett (1974, pl. 26, Fig. 4c).

In the British Isles, it is known only from rare occurrences in the Wenlock shale and Limestone in Shropshire, Dudley and Walsall.

Genus Katastrophomena Cocks, 1968

Katastrophomena (Katastrophomena) penkillensis (Reed, 1917) (Fig. 6)

v.1916 Strophomena antiquata (J. de C. Sowerby).Holtedahl: 58, pl. 10, Fig. 10

v*1917 Strophonella penkillensis—Reed: 900, pl. 18, Figs. 11-14

v.1968 Katastrophomena penkillensis Reed.-Cocks: 297, pl. 4, Figs. 1-6

v.1974 Katastrophomena sp.-Bassett: 110, pl. 28, Fig. 12

Description: Exterior: Shell outline rounded triangular with the maximum width usually at the hinge line, but sometimes slightly anterior to this. The lateral margins of the hinge line are normally produced as quite sharp alae. Shell length usually about $60-70 \%$ of width, but in some specimens the $\mathrm{L} / \mathrm{W}$ ratio approaches $1 / 1$. Initially the ventral valve is weakly convex, but then becomes resupinate, and the growing edge is deflected weakly ventrally to produce a gently concave ventral disc. The dorsal valve is initially weakly concave or flat, but becomes weakly convex during growth; at about half length a more strongly ventral deflection occurs, making the valve quite strongly convex. The commisure is mostly in a single plane, but with a slight dorsal fold anteromedially. Dorsal umbo is low and inconspicuous, ventral beak erect, often having a small foramen open on the outside, but plugged internally.
Ventral interarea relatively low, about $5 \%$ of hinge width. Delthyrium wide, usually covered only apically by a small pseudodeltidium, but some specimens have a pseudodeltidium that covers the whole delthyrium. Dorsal interarea much lower than the ventral area, with a small chilidium covering only the proximal parts of the cardinalia. Radial ornament finely parvicostellate, with thin costellae with $4-5$ very fine fila in the interspaces, from some of which new costellae gradually arise. Concentric ornament of fine growth lines, some specimens display two or three strong growth ridges, indicating periodic cessation of growth. A very few specimens (Fig. 6A, G) exhibit irregular rugae, which are deflected when crossing a costella, creating a zig-zag pattern similar to that of Bellimurina (see above).

Ventral interior: Delthyrial cavity deep, roofed over by the pseudodeltidium. The innermost part is filled by the posterior part of the median ridge of the muscle field, which here has a median depression and extends to the apex of the shell, obliterating the inner end of the apical foramen. The teeth are relatively small and bluntly triangular, with vertical striations on their posterior face. Dental plates blend smoothly into the muscle-bounding ridges. Ventral muscle field round to diamond-shaped, with L/W ratio from 0.65 to 0.85 . The adductor scars occupy the anterior half of the muscle field, on both sides of the median ridge; their width is about $33 \%$ of the width of the muscle field. The muscle bounding ridges do not meet anteriorly, but are deflected forwards on both sides of the median ridge for a short distance anterior to the muscle field. The extra-muscular area is covered with very small taleolae, slightly larger ones occur close to the muscle field; vascular traces are rarely present, but some specimens (e.g., Fig. 6E) preserve bifurcating mantle canals close to the margin.

Dorsal interior: The cardinalia are raised on a short, high notothyrial platform. Cardinal process lobes stout, tubular and posteriorly directed, with strong striation on the muscle attachment facets. Socket plates strong, fused with the notothyrial platform, curving anterolaterally then laterally, diverging about $145^{\circ}$ from one another; the crest of the socket plate curves ventroposteriorly around the socket, making the socket into a half-pipe shaped trough with its opening towards the rear of the animal. Muscle field deeply impressed posteriorly; the muscle scars are separated by a rounded median ridge produced anteriorly from the notothyrial platform, and which bifurcates anteriorly. A thin median ridge originate at the front of the adductor scars. Each lateral adductor scar is rounded posteriorly, and the anterior part of each becomes rectangular and blade-like during ontogeny; the anterolateral ends overhang the valve floor. A thin groove separates the lateral from the median 


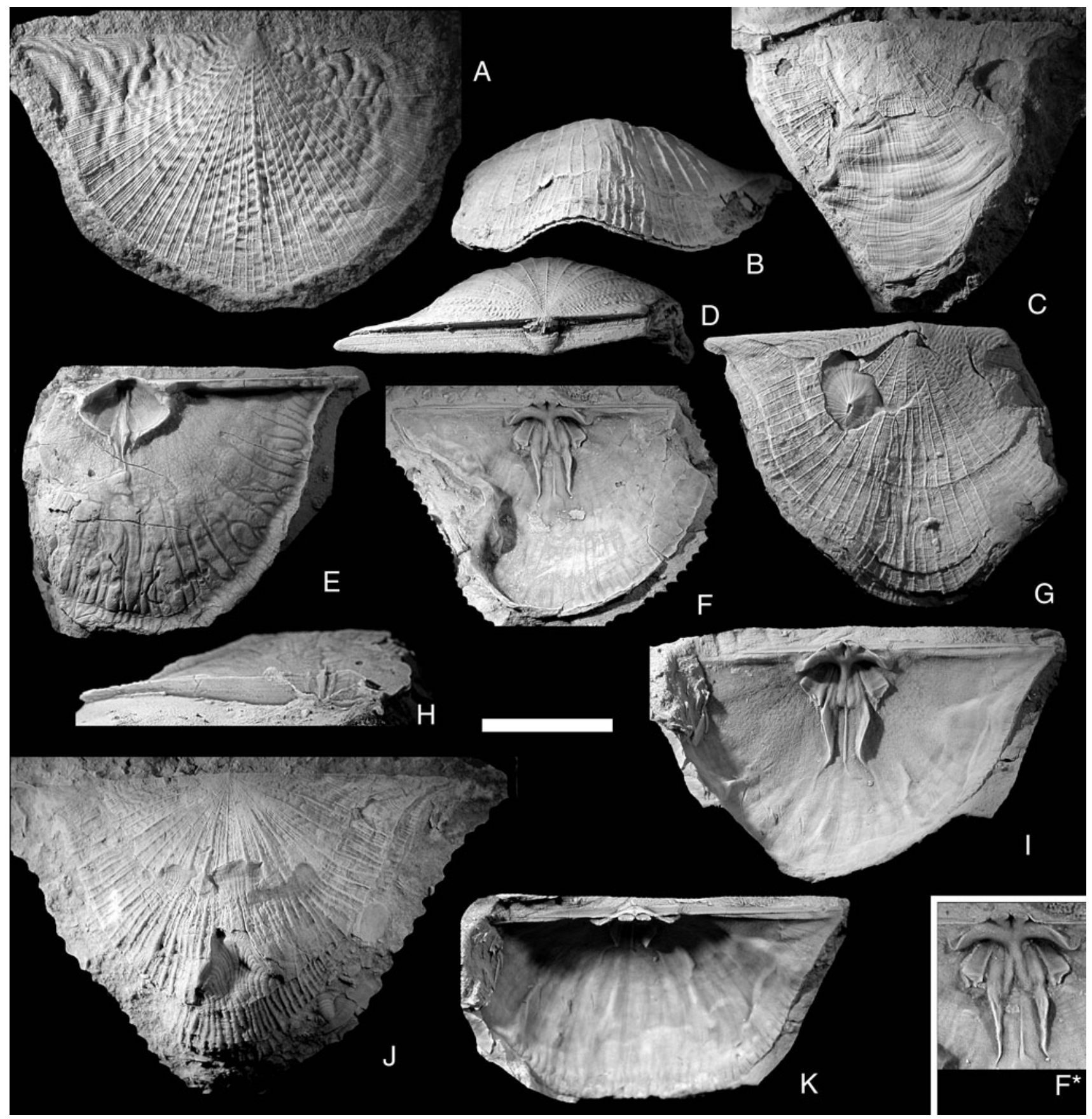

Fig. 6 Katastrophomena penkillensis (Reed, 1917). All from the upper Visby Formation at Gnisvärd, Tofta unless otherwise indicated. Scale bar $1 \mathrm{~cm}$. A NRM Br 35612, Högklint Formation, Visby; ventral valve with particularly well-developed rugae; B, D, G NRM $\mathrm{Br}$ 35559; frontal, posterior and ventral views, note repaired hole in shell; C NRM Br 35637a; ventral view, note the enormous area of

adductor scar; the median scar is narrow and short, the ridge on which it is placed continues forwards to become a long, high, sinuous ridge, which encloses the anterior scars and then bends laterally to blend into the valve floor. The entire valve interior, except the surface of the median and healed shell damage; E, H NRM Br 138200; ventral interior with particularly strong mantle canals, dorsal and posterior views; $\mathbf{F}$ NRM Br 138199b; dorsal interior, note the indented lateral shell margin; I, K NRM Br 138199a; dorsal interior in ventral and posterior views; J NRM Br 35566, Högklint Formation, Medebys, Hall; ventral view, note several instances of shell repair

lateral adductor scars, is covered with minute pustules. The muscle scars are smooth or have impressions of the muscle fibers. There are no clear vascular traces, but the surface near the commisure has short, regular grooves perpendicular to the valve edge. 
Remarks: These Gotland specimens are assigned to $K$. penkillensis on the basis of the sculpture of unequally sized costellae, but as the preservation is different from the British specimens figured by Cocks (1968), they are not easy to compare. The overall shape is quite similar, but the dorsal muscle field seems to be more strongly developed in the Gotland specimens, especially the anterior paired ridges in front of the muscle scars. Apparently the convexity of the dorsal valve is also greater in the Gotland material.

A closely similar form is the specimen figured by Bassett (1974, pl. 28, Fig. 12) from the lower Wenlock of Sawdde Gorge, Carmarthenshire, which has similar sculpture and shape of the ventral muscle field, and also similar long triangular outline.

The shells are often damaged during growth, resulting in areas with abnormal ornamentation, usually very subdued radial sculpture and more pronounced growth lines. One of the specimens (Fig. 6C) apparently lost and regrew more than half of its shell. Another (Fig. 6G) repaired a hole punched through the dorsal valve within the visceral area.

Distribution: On Gotland, the species is known from the lower and upper Visby Formation, the Högklint Formation, and the Slite marl around Klintehamn in the SW part of the Slite group.

In Norway, it is known only from the single specimen figured by Holtedahl (1916, pl. 10, Fig. 10), which comes from the probably latest Llandovery Bruflat Formation of Storøya in the Ringerike District. Deposition here was in a quiet, muddy environment below the normal wave base (see Worsley et al. 1983, p. 27), which was quite similar to the environment of the Visby Formation on Gotland.

In the British Isles, the species occurs in the uppermost Llandovery of Ayrshire (Scotland) and Shropshire (Cocks 1968). It is probably also present in the lower Wenlock of Sawdde Gorge, Carmarthenshire (Bassett 1974).

Katastrophomena (Katastrophomena) antiquata scabrosa (Davidson, 1847) (Fig. 7)

v*1847 Orthis scabrosa-Davidson: 61, pl. 13, Figs. 14, 15

v.1848 Leptaena scabrosa (Davidson)._Davidson: 318, pl. 3, Fig. 13

v.1848(part) Leptaena antiquata (J. de C. Sowerby).Davidson: 319, pl. 3, Fig. 11 left hand fig., non right hand fig., non J. de C. Sowerby in Murchison, 1839

v.1848 Strophomena scabrosa (Davidson).D’Orbigny in Davidson: 336 [name only]

v.1861 Strophomena scabrosa (Davidson).Lindström: 372 [name only] v.1871(part) Strophomena antiquata (J. de C. Sowerby).—Davidson: 299, pl. 44, Figs. 6, 10-13, non Figs. 2-5, 7-9, 21, 22, non J. de C. Sowerby in Murchison, 1839

1949 Strophomena scabrosa (Davidson).Bancroft: 13, pl. 1, Figs. 12-15

v.1949 Strophomena dura-Bancroft: 15, pl. 1, Fig. 11

v.1968 Katastrophomena scabrosa (Davidson).Cocks: 293 [reference to name only]

v.1968 Katastrophomena dura (Davidson).Cocks: 293 [reference to name only]

v.1974 Katastrophomena scabrosa (Davidson).Bassett \& Cocks: 13

v.1974 Katastrophomena antiquata scabrosa (Davidson).-Bassett: 107, pl. 27, Figs. 9-12, pl. 28, Figs. 1-6

Remarks: This subspecies was described in detail by Bassett (1974) together with K. antiquata antiquata (J. de C. Sowerby, 1839). Bassett (1974) found that the only difference between the two named subspecies and further specimens described by him under open nomenclature was in the degree of ornament development. He therefore suspected that they all belong to the same, widely variable species, but refrained from putting them in synonymy pending better collections. The specimens from Gotland usually are similar to $K$. antiquata antiquata in having a more transverse, semicircular outline rather than the subtriangular outline of $K$. antiquata scabrosa, but the ornament is similar to that of the latter subspecies. Specimens from the high-energy environments of the eastern Slite group and the Klinteberg Formation have costellae that are strong, tightly packed and frilly, while specimens from the lower energy environment of the Hemse group have more widely spaced costellae, as seen in the specimens referred to as K. antiquata subsp. B by Bassett (1974, pl. 28, Figs. 10, 11).

$K$. antiquata scabrosa can be distinguished from K. penkillensis (Reed, 1917) from the Visby-Slite units (see above) by its semicircular outline and much coarser radial ornament. In the dorsal interior the difference between the species is quite pronounced in the adductor muscle scars; $K$. penkillensis has very wide lateral adductor scars and very narrow medial adductor scars, whereas $K$. antiquata scabrosa has narrow lateral adductor scars and wide medial adductor scars.

Distribution: The species is known from the easternmost end of the late Sheinwood Slite group at Slite, in the latest Wenlock Klinteberg Formation at Klinteberg and Lilla Karlsö, and in the western part of the lower Hemse group (early Ludlow) from Petesvik to Sandarve. 


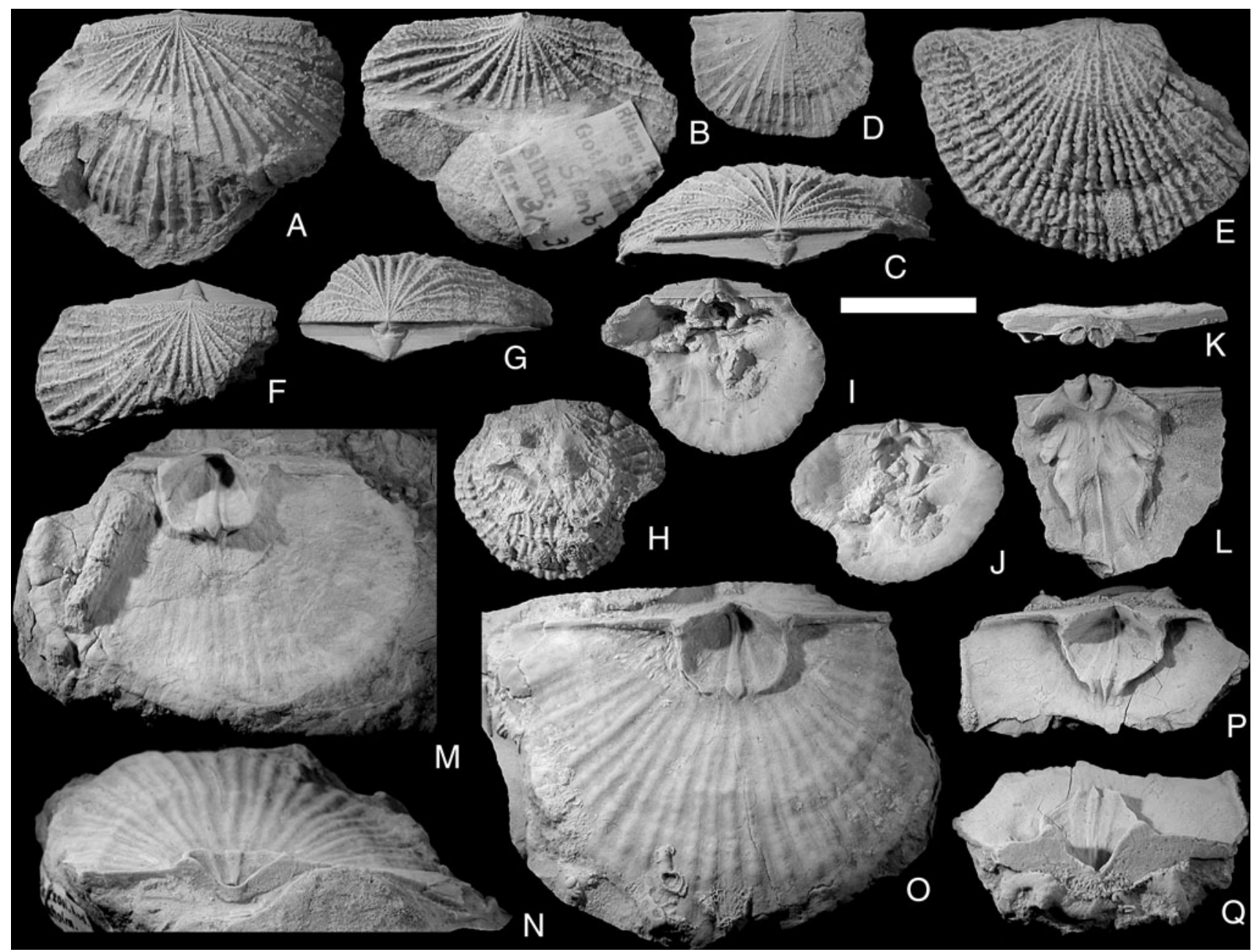

Fig. 7 Katastrophomena antiquata scabrosa (Davidson, 1847). Scale bar $1 \mathrm{~cm}$. A-C NRM Br 35374, Hemse group, Stenbro A, Othem; conjoined valves in dorsal, ventral and posterior views; D NRM Br 35589, Hemse Group, Petesvik, Hablingbo; small conjoined valves, ventral view; E NRM Br 35569, Klinteberg Formation, Klinteberg, Klinte; ventral view of conjoined valves; F, G NRM Br 35369, Hemse group, Petesvik, Hablingbo; incomplete conjoined valves, dorsal and posterior views; H-J NRM Br 138065, Slite group,

In the British Isles, it occurs in the Wenlock Limestone of Benthall Edge, Dudley, Sedgley, Walsall and the May Hill Inlier, and the "Lower Ludlow Shale" of Dudley and Sedgley (Bassett 1974, p. 109)

Family Leptostrophiidae Caster, 1939

Genus Mesoleptostrophia Harper \& Boucot, 1978

Subgenus Mesoleptostrophia (Mesoleptostrophia)

Harper \& Boucot, 1978

Type species: By original designation; M. kartalensis Harper \& Boucot nom. nov. pro Stropheodonta (Leptostrophia) explanata Paeckelmann \& Sieverts, 1932, non Sowerby, 1842 in $1840-1846$, p. 40 . The type species is from the lower Devonian of Turkey.
Solklint 1, Othem; exterior and two interior views of dorsal valve with unusual, circular outline; K, L NRM Br 114780, Hemse group, Petesvik, Hablingbo; posterior and ventral views of incomplete dorsal valve; M NRM Br 35568, Klinteberg Formation, Klinteberg, Klinte; ventral interior; N, O NRM Br 35372, Hemse group, Stenbro A, Othem; posterior and dorsal views of ventral interior; $\mathbf{P}, \mathbf{Q} \mathrm{NRM} \mathrm{Br}$ 114779, Hemse group, Petesvik, Hablingbo; dorsal and posterior views of incomplete ventral valve

Mesoleptostrophia (Mesoleptostrophia) filosa (J. de C. Sowerby, 1839) (Fig. 8)

v*1839 Orthis filosa-J. de C. Sowerby in Murchison: 630, pl. 13, Fig. 12

v.1846 Orthis filosa J. de C. Sowerby.-M'Coy: 30

v.1847 Orthis filosa J. de C. Sowerby.-Davidson: 62, pl. 13, Fig. 24

1848 Leptaena filosa (J. de C. Sowerby).—Davidson: 318, pl. 3, Fig. 9

1848 Strophomena filosa (J. de C. Sowerby).—Phillips \& Salter: 380

1861 Strophomena filosa (J. de C. Sowerby).Lindström: 373 


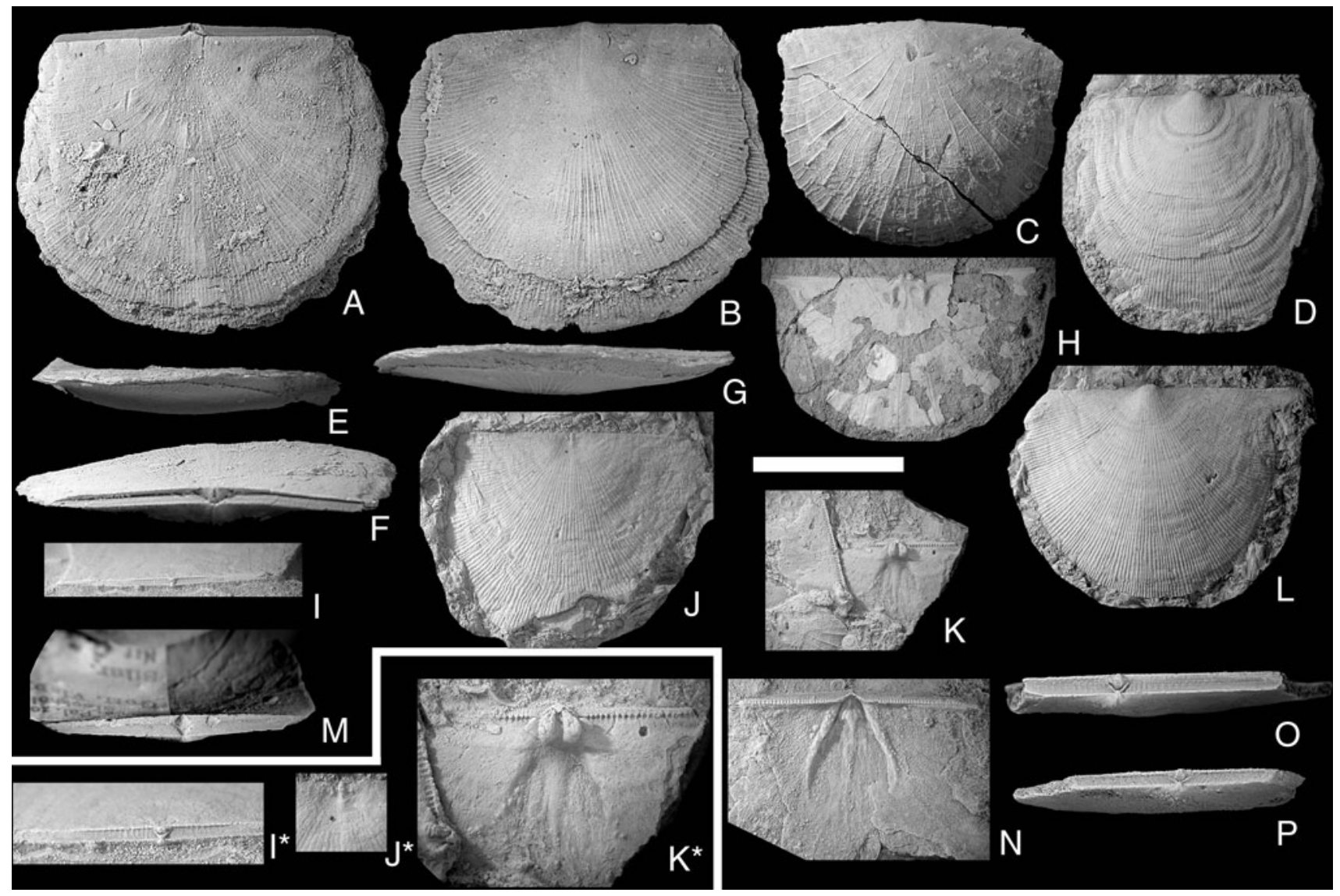

Fig. 8 Mesoleptostrophia (Mesoleptostrophia) filosa (J. de C. Sowerby, 1839). Scale bar $1 \mathrm{~cm}$, except in figures $\mathbf{I}^{*}, \mathbf{J}^{*}$ and $\mathbf{K}^{*}=0.5 \mathrm{~cm}$. A, B, E-G NRM Br35697; posterior, anterior, lateral, ventral and dorsal views of conjoined valves; Hemse group, Sandarve kulle, Fardhem; D NRM Br36095. Ventral valves; Hamra or Sundre Fm., Gervalds, Vamlingbo; C, M NRM Br34671. Posterior and ventral views of conjoined valves; Högklint Fm., Visby; H NRM Br138227. Interior view of small dorsal valve with extremely thin shell; Hemse group, Lau kanal, Lau; I, I* NRM Br32921; posterior view and detail of conjoined valves; Hemse group, Petesvik,
Hablingbo; J, J* NRM Br36086. Complete and detail view of dorsal valve; Hamra or Sundre Fm., Gervalds, Vamlingbo; K, K* NRM Br129894. Group and detail view of small, but robust dorsal valve; Hemse group, Ringome, Alva; L NRM Br36088; Ventral valves; Hamra or Sundre Fm., Gervalds, Vamlingbo; N NRM Br109714. Ventral interior; Hemse group, Petesvik, Hablingbo; O NRM Br32937; posterior view of conjoined valves; Hemse group, Petesvik, Hablingbo; P NRM Br32938; posterior view of conjoined valves; Hemse group, Petesvik, Hablingbo
1871 Strophomena filosa (J. de C. Sowerby).Davidson: 307, pl. 45, Figs. 14-20

1884 Strophomena filosa (J. de C. Sowerby).-La Touche: 70, pl. 13, Figs. 406, 407

1893 Leptostrophia filosa (J. de C. Sowerby).-Hall \& Clarke: 288 [name only]

1921 Leptostrophia filosa (J. de C. Sowerby).-Hede: 92 [name only]

1951 Leptostrophia filosa (J. de C. Sowerby).Williams: 125 [name only]

1963 Leptostrophia filosa (J. de C. Sowerby).Holland et al.: pl. 3, Figs. 3, 5

1971 Leptostrophia (Leptostrophia) filosa (J. de C. Sowerby).-Bassett: 315, pl. 56, Figs. 9, 10; pl. 57, Figs. 1-6
1974 Leptostrophia filosa (J. de C. Sowerby).-Calef \& Hancock: pl. 106, Fig. 12

1974 Leptostrophia filosa (J. de C. Sowerby).Bassett \& Cocks: 15

1977 Leptostrophia (Leptostrophia) filosa (J. de C. Sowerby).-Bassett: 145, pl. 39, Figs. 3-8

1978a Leptostrophia (Leptostrophiella) filosa (J. de C. Sowerby).-Harper \& Boucot: 75 [name only]

?1978a Leptostrophia (Leptostrophiella) sp.-Harper \& Boucot: pl. 5, Figs. 4a, b, 6, 8a, b

Lectotype: GSM Geological Society Collection 6644, external mold of dorsal valve; from the Wenlock Coalbookdale Formation of Old Castle, Malvern Hills, UK; selected and figured by Bassett 1971, p. 317, pl. 57, Fig. 5; 
originally figured J. de C. Sowerby in Murchison 1839, pl. 13, Fig. 12.

Remarks: Harper and Boucot (1978a) assigned M. (M.) filosa to their new subgenus Leptostrophia (Leptostrophiella). This subgenus was regarded by Rong and Cocks (1994) as a subjective synonym of Mesoleptostrophia, and I agree with them that the species does not belong to Leptostrophia since there are no radial ridges within the ventral muscle field. There is also a ventral process rather than a tubular chamber, and the ornament has no hint of rugae.

The description of this species by Bassett (1977, p. 145) is generally applicable also for the Gotland specimens, with the following amendments. Many of the Gotland specimens are almost as long as wide; ornament is usually fine, equally parvicostellate, but can be unequally parvicostellate (Fig. 8C) or coarsely costellate (Fig. 8J, L); the former pattern is seen in low-energy the latter in high-energy environments; almost the entire hinge line is denticulate.

Distribution: On Gotland M. (M.) filosa is the most widespread strophomenide, both geographically and temporally. It occurs throughout the succession from the Visby Formation to the Hamra Formation, in all environments. Although widespread, it seems to be especially common in relatively high energy settings; it is one of the few strophomenides found in the shallow water, very highenergy stromatoporoid-dominated environments of the eastern part of the Klinteberg Formation and Hemse group (the others being Leptaena depressa depressa, Lepidoleptaena poulseni and Shaleria (Janiomya) ornatella). It is also fairly common in the Wenlock of the Welsh Borderland and South Wales, but rare or absent after mid-Ludlow times.

Genus Brachyprion Shaler, 1865

Subgenus Brachyprion (Brachyprion) Shaler, 1865

Type species: By original designation; Strophomena leda Billings, 1860, p. 55, Figs. 2, 3; Jupiter Formation, Anticosti Island.

Remarks: In the Silurian, small and moderately concavo-convex leptostrophiids have generally been referred to Brachyprion, while larger and more deeply concavo-convex ones have been referred to Protomegastrophia Caster, 1939. However, the redescription of the type species of Brachyprion, B. leda (Billings, 1860) by Dewing (1999) shows that even if that species is usually relatively small, there is great variation in convexity. The range of variation in convexity of $B$. leda is very similar to that seen in the material of B. (B.) semiglobosa from Gotland. Harper and Boucot (1978c) separated Brachyprion and Protomegastrophia (as subgenera of Brachyprion) only by the presence (in Protomegastrophia) or absence (in Brachyprion) of the alveolus (the cardinal process pit of Williams et al. 1997, p. 424). In the Anticosti material of B. leda described by Dewing (1999), this character is present in some specimens and absent in others. He therefore treated the two (sub)genera as being synonymous. Cocks and Rong (2000) separated Eomegastrophia, Brachyprion and Protomegastrophia on the basis of degree of concavoconvexity and the strength of the ventral muscle-bounding ridges. The ornament varies equally in all three genera. The youngest genus (Protomegastrophia) has stronger convexity and more strongly impressed muscle fields than the two earlier taxa, but both these traits are typical of large-sized specimens. Here I follow the opinion of Dewing (1999); he considered Protomegastrophia to be a junior synonym of Brachyprion (Brachyprion), lacking dental plates, while the presence of these plates in Eomegastrophia made him include that taxon as a subgenus of Brachyprion. I consider Brachyprion to also contain B. (Erinostrophia) (see below for an emended diagnosis and discussion of this subgenus).

\section{Brachyprion (Brachyprion) semiglobosa (Davidson, 1871) (Fig. 9)}

v.1847 Leptaena imbrex (Pander).-Davidson: 55, pl. 12, Figs. 25-28;-non Pander 1830

v.1848 Leptaena imbrex (Pander).-Davidson: 318, pl. 3, Fig. 8;-non Pander 1830

v.1854 Strophomena imbrex (Pander).--Salter in Murchison: table on p. 488, woodcut 41, p. 224, Figs. 6, 7; -non Pander 1830

v*1871(part) Strophomena imbrex (Pander) var. semiglobosa Davidson.-Davidson: 286, pl. 41, Figs. 1-4, non Figs. 5, 6

v.1883 Strophomena imbrex var. semiglobosa Davidson.-Davidson: 195

v.1953 Megastrophia semiglobosa (Davidson).Williams: 21

v.1971(part) Megastrophia (Protomegastrophia) semiglobosa (Davidson)._Bassett: 308, pl. 54, Figs. 9-13, pl. 55, Figs. 1, 2; non pl. 55, Fig. 3

v.1974 Megastrophia (Protomegastrophia) semiglobosa (Davidson).-Bassett \& Cocks: 17

v.1974(part) Brachyprion spp.-Bassett \& Cocks: 15 [partim]

v.1977 Megastrophia (Protomegastrophia) semiglobosa (Davidson).-Bassett: 141, pl. 37, Figs. 1-5

?1978c(non?) Brachyprion (Protomegastrophia) cf. semiglobosa (Davidson).--Harper \& Boucot: 18, pl. 38, Fig. 4, 6-8, non? Figs. 3, 5 


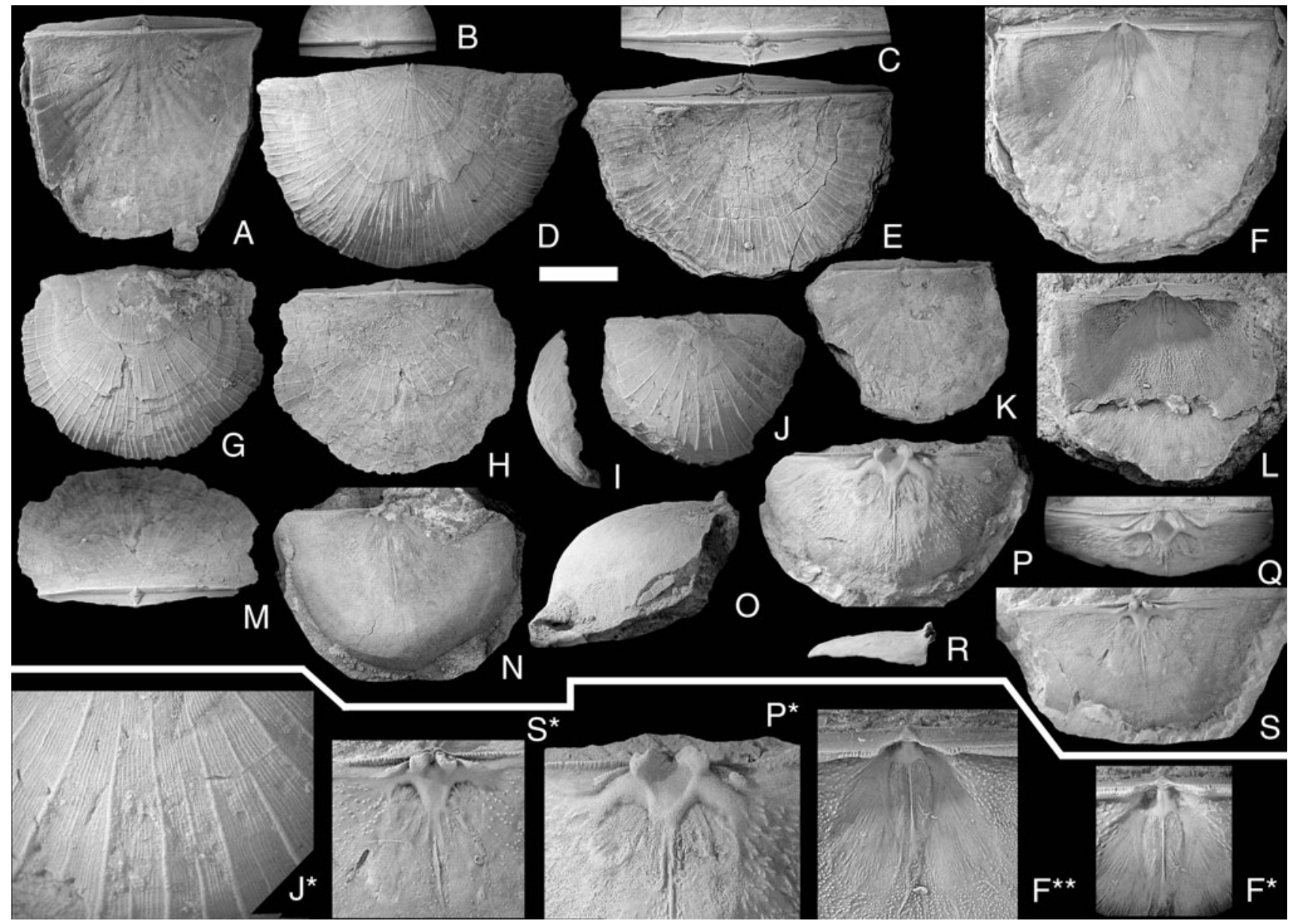

Fig. 9 Brachyprion semiglobosa (Davidson, 1871). Scale bar $1 \mathrm{~cm}$, except in figures $\mathbf{F}^{*}, \mathbf{F}^{* *}, \mathbf{P}^{*}, \mathbf{S}^{*}=0.5 \mathrm{~cm}$, and Fig. $\mathbf{J}^{*}=0.3 \mathrm{~cm}$. A, B NRM Br118262. dorsal and posterior views of conjoined valves; Slite group, Västergarn, Västergarn; C-E NRM Br34685. Ventral, posterior and dorsal views of conjoined valves; ?Högklint Fm., Väskinde; $\mathbf{F}, \mathbf{F}^{*}, \mathbf{F}^{* *}$ NRM Br 131189. Ventral valve interior; views: $\mathbf{F}, \mathbf{F}^{* *}$ perpendicular to the commisure; $\mathbf{F}^{*}$ parallel with the interarea; Upper Visby Fm., Gnisvärd, Tofta; G, H, M NRM Br34689. Ventral, dorsal and posterior views of conjoined valves; ?Högklint Fm.,
Väskinde; I-K, J* NRM Br33874. Lateral, ventral and dorsal views of conjoined valves. $\mathbf{J}^{*}$; detail of ventral valve sculpture; Slite group, Stora Karlsö; L NRM Br119571. Ventral valve interior, view perpendicular to the interarea; Högklint Fm., Visby; N, O NRM Br123373. Ventral and lateral views of semicircular, strongly vaulted dorsal valve; Slite group, Bäcks, Akebäck; P, Q, P* NRM Br35914. Ventral and posterior views of semicircular, strongly vaulted dorsal valve; Slite group, Atlingbo church; $\mathbf{R}-\mathbf{S}, \mathbf{S}^{*}$ NRM Br35895. Lateral and ventral views of wide, flat dorsal valve; Visby Fm., Visby v.1978c Brachyprion (Protomegastrophia) sp.Harper \& Boucot: pl. 37, Figs. 1-11, pl. 38, Fig. 9

v.2004 Brachyprion sp.-Musteikis \& Cocks: 464

Remarks: The species was described by Bassett (1977), and there is little to add to his description. As noted by Bassett (1977, p. 142), the Gotland material displays wide variability in profile; most are more elongate and less deeply convex than the British specimens. Some Gotland specimens also have the more widely spaced primary costellae seen in P. quetra Bassett (1977, p. 142), but are not as large and thick-shelled as that species.
Distribution: B. (Brachyprion) semiglobosa is common in all environments within the lower part of the Gotland succession, from the Visby Formation through the whole of the Slite group. A few specimens have also been found in the Klinteberg Formation at Klinteberg. There is no evidence to suggest that it is present further east in the Baltic (Musteikis and Cocks 2004). In the British Isles it occurs in the upper Llandovery of the Malvern area (Harper and Boucot 1978c, pl. 38, Figs. 4, 6-8), and it is relatively rare in the upper Wenlock of the Welsh Borderlands and south-central Wales (Bassett 1977, p. 140). Possibly the specimens from the upper Wenlock of the Llandovery area figured by Harper and Boucot (1978c, pl. 38, Figs. 3, 5) also belong to this species. 


\section{Subgenus Brachyprion (Erinostrophia) Cocks \&} Worsley, 1993

Type species: By original designation; Orthis undata M'Coy, 1846; p. 36.

Emended diagnosis: Strongly concavo-convex; pronounced but discontinuous rugae over whole shell in most specimens. Cardinal process lobes rounded, undercut laterally; dorsal muscle bounding ridges absent; dorsal adductor scars narrow, centrally placed; transmuscle ridges long and strong, almost parallel to the midline, diverging less than $15^{\circ}$ from the mid line of the valve.

Remarks: The subgenus was erected (as a genus) entirely on the basis of its distinctive ornament of irregular rugae, but this feature is very subdued on many of the Gotland specimens of $E$. walmstedti, and firmer grounds for separation should be established to warrant recognition. Cocks and Worsley (1993, p. 44) noted that the cardinal process lobes of Erinostrophia and Protomegastrophia are erect, whereas those of Brachyprion leda are anterior-facing. As discussed above, Protomegastrophia is considered a junior synonym of Brachyprion, and the cardinal process lobes of B. (Brachyprion) semiglobosa are indeed erect like those of E. walmstedti.

B. (Erinostrophia) differs from B. (Brachyprion) in having rugae, in the shape of the notothyrial platform, which lack muscle bounding ridges completely, in the laterally undercut cardinal process lobes, in having centrally placed dorsal adductor scars and in having almost parallel transmuscle ridges. B. (Erinostrophia) differs from B. (Eomegastrophia) in lacking dental plates and in having a more deeply impressed ventral muscle field, which usually has an unbounded anterior margin.

Brachyprion (Erinostrophia) walmstedti (Lindström, 1861) (Fig. 10)

?1846 Orthis undata-M'Coy: 36, pl. 3, Fig. 21

v*1861 Strophomena walmstedti-Lindström: 372, pl. 13, Fig. 16

v.1868 Strophomena walmstedti Lindström.Davidson: 18, pl. 3, Figs. 5-7

v.1871 Strophomena walmstedti Lindström.Davidson: 290, pl. 40, Figs. 6-8

v.1916 Brachyprion walmstedti (Lindström).Holtedahl: 39-40, pl. 5, Figs. 6-8

v.1974 Megastrophia (Protomegastrophia) walmstedti (Lindström).-Bassett \& Cocks: 16, pl. 3, Figs. 5-9

v.1978 Brachyprion (Brachyprion) walmstedti (Lindström).--Harper \& Boucot: 16 v.1978

v.1993(part?) Erinostrophia undata (M'Coy).—Cocks \& Worsley: 44-45, Fig. 8b-f, ?non Fig. 8a

Type specimens

Lectotype of walmstedti (selected by Bassett \& Cocks 1974, p. 16): NRM Br102367, conjoined valves; original of Lindström 1861, pl. 13, Fig. 16, from the lower Visby Formation (Telychian), Visby, Gotland, Sweden. Refigured by Bassett and Cocks 1974, pl. 3, Fig. 5a-d.

Lectotype of undata (selected by Cocks 1978, p. 128): NMING: F7475, an internal mould of a dorsal valve; original of M'Coy 1846, pl. 3, Fig. 21 from Kilbride Sandstone (Telychian), Egool, Ballaghadareen, County Mayo, Ireland. Refigured by Cocks and Worsley 1993, Fig. 8A.

Diagnosis: Cardinal process lobes strong, divergent, strong socket ridges, and long, subparallel dorsal transmuscle ridges.

Description: The species was described adequately by Bassett and Cocks (1974, p. 16), but as some of the material they studied apparently was badly preserved, some additions to their description of the ventral interior can be made: Ventral muscle field deeply recessed, but without muscle bounding ridges, except anterior to the diductor scars, where there is a very low rim. Muscle field divided longitudinally by a thin, low median ridge, which swells somewhat anterior to the adductor scars and dies out at the anterior margin of the diductor scars. Delthyrial cavity filled by the large ventral process, which extends forwards and is forked rather far posteriorly. On both sides of the ventral process there are deep pits accommodating the cardinal process lobes; anterior to these there is a smooth surface lateral to the adductor scars and posterior to the recessed diductor scars. Posterior adductor scars large, triangular; anterior adductor scars small, rounded. Diductor scars large, recessed and kidneyshaped, with unbounded anterior margin. There is no trace of the muscle scars being flabellate as believed by Bassett and Cocks (1974). The extra-muscular area has coarse taleolae lateral to the muscle field, but anteriorly the surface is covered by very densely packed, minute taleolae. The vascula media bifurcate several times anteriorly, forming a large number of relatively wide mantle canals at the commisure, but only along the anterior half of the commisure; posteriorly there are no vascular traces.

Remarks: Cocks (1978) placed B. (E.) walmstedti into synonymy with $B$. (E.) undata (M'Coy, 1846), solely on 


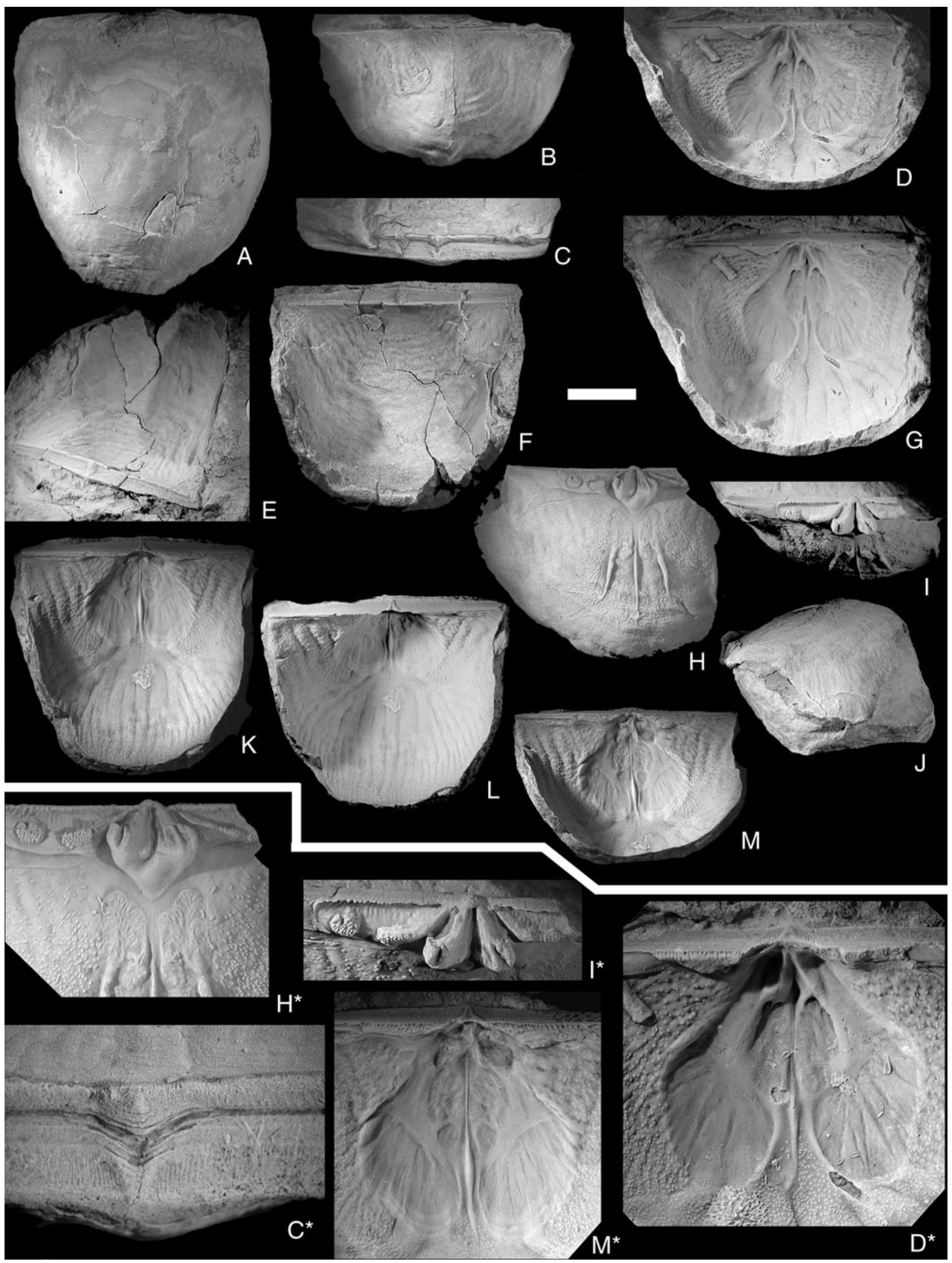


4 Fig. 10 Brachyprion (Erinostrophia) walmstedti (Lindström, 1861). Scale bar $1 \mathrm{~cm}$, except in figures $\mathbf{D}^{*}, \mathbf{H}^{*} ; \mathbf{I}^{*}, \mathbf{M}^{*}=0.5 \mathrm{~cm}$, $\mathbf{C}^{*}=0.2 \mathrm{~cm}$. A-C, C* PMU EP203. Conjoined valves. Ventral, posteroventral, interareal views and detail of delthyrial area to show pattern of growth by mantle retractions; D, G, D* NRM Br33988. Ventral interior. Views parallel to the interarea and normal to the commisure, with detail of the muscle field. Note how the diductor scars are sharply delimited posteriorly; E, F PMU EP201. Conjoined valves. Views from the postero-lateral side and normal to the commisure; H-J, $\mathbf{H}^{*}-\mathbf{I}^{*}$ SGU 9221. Dorsal valve. Interior, posterior, lateral views, and detail of the cardinal area. Note the kidney-shaped adductor scars and the round "secondary socket ridge"; $\mathbf{K}-\mathbf{M}, \mathbf{M} *$ SGU 9222. Ventral valve. Views normal to the commisure, normal to the interarea and parallel to the interarea, with detail of muscle field. Note the small anterior adductor scars

the basis of the presence of rugae on both forms. $B .(E$. undata is not well known; only the single badly preserved lectotype has ever been found, and it does not show much detail apart from the sculpture, but judging from the photograph in Cocks and Worsley (1993, Fig. 8a), the cardinal process seems to be relatively much smaller than in the Gotland specimens and also smaller than in the Norwegian specimens figured by the same authors (Fig. 8e, f). Davidson (1879, p. 290, pl. 40) assigned specimens from the Pentland Hills to walmstedti rather than undata, despite having seen M'Coy's material. I therefore retain the species name walmstedti until study of better material of the Irish species can confirm the synonymy or otherwise of the two forms.

Distribution: On Gotland, B. (E.) walmstedti occurs quite commonly in both the lower (Telychian) and upper (Sheinwoodian) parts of the Visby Formation along the northwest coast from Lummelunda in the north to Tofta in the south. In the Oslo Region (Norway), it is common in the upper part of the Bruflat and Porsgrunn formations (latest Telychian) and in the Braksøya Formation (Sheinwoodian) (Worsley et al. 1983, Cocks and Worsley 1993), and it also occurs in the Telychian of the Pentland Hills, Borders Region, UK (Davidson 1871, p. 290). Most of these occurrences appear to be in relatively shallow, but low-energy depositional environments.

Family Strophodontidae Caster, 1939

Genus Strophodonta Hall, 1850

Subgenus Strophodonta (Strophodonta) Hall, 1850

Type species: By original designation; Strophomena demissa Conrad, 1842, p. 258, pl. 14, Fig. 14; from the Emsian-Givetian of New York and the Eifelian-Frasnian of Maryland, USA.

\section{Strophodonta (Strophodonta) hoburgensis n. $\mathbf{s p .}$ (Fig. 11)}

Derivation of name: From the type area of the species.
Holotype: NRM $\mathrm{Br}$ 102617a, a dorsal valve interior, from the Hamra Formation at Hoburgen, Sundre parish, Gotland, figured in Fig. 11I, I*.

Diagnosis: Profile moderately concavoconvex, strong, uniformly costellate sculpture, denticles along about half the hinge line, raised adductor scars in the ventral valve; dorsal muscle scars faint, transmuscle ridges wide and strong distally.

Description: Shell outline usually semicircular, widest at the posterolateral margins; the latter are often extended into long, rather thin alae. Profile moderately concavoconvex without any geniculation; ventral beak prominent, in some specimens with a small apical foramen, overhanging the hinge line. Ventral interarea short, weakly apsacline at the umbo, but catacline towards the hinge line; traces of the growth path of denticles is visible. Delthyrium very narrow near the apex where it is covered by a small pseudodeltidium, and subsequently widens sharply towards the hinge line. Dorsal interarea shorter than the ventral area, anacline, nothothyrium small, filled by the cardinal process and covered by a small chilidium. Ornament of coarse, subequal, slightly irregular parvicostellate, about 2 per $\mathrm{mm}$.

Delthyrial cavity filled by strong ventral process, which is slightly concave centrally, process pits shallow but almost as large as the adductor scars. No trace of teeth, denticles along about half shell width. Muscle field occupies $50 \%$ of shell length and $33 \%$ of valve width, triangular, slightly depressed but without bounding ridges. Adductor scars large, bean-shaped, raised above the valve floor and separated by a median ridge, which is concave centrally; this ridge dies out at the anterior end of the adductor scars, but anterior to this there is a slight swelling which bifurcates into two low, wide ridges, which encircle a shallow depression at about $50 \%$ of valve length. Diductor scars long and wide, anterior end of muscle scars indistinct, but on weathered specimens a discoloration shows the anterior end to be rounded. The extra-vascular area is covered with large pseudopunctae, which are larger and more pronounced lateral to the muscle field and around the anterocentral depression.

In the dorsal valve, there is neither a bounding ridge nor a clear geniculation, but a slight increase of curvature outside the muscular area is visible in some specimens; hinge line denticulate along more than $50 \%$ of its length, usually about $75 \%$. Socket ridges very short, subparallel with hinge line. Cardinalia strong, raised on a notothyrial platform, which is elevated and curves around the posterior of the adductor scars in young specimens, but is recessed in gerontic ones. Cardinal process lobes massive, rising vertically from the notothyrial platform, joined proximally, slightly diverging, with attachment faces pointing posteriorly. Adductor scars 


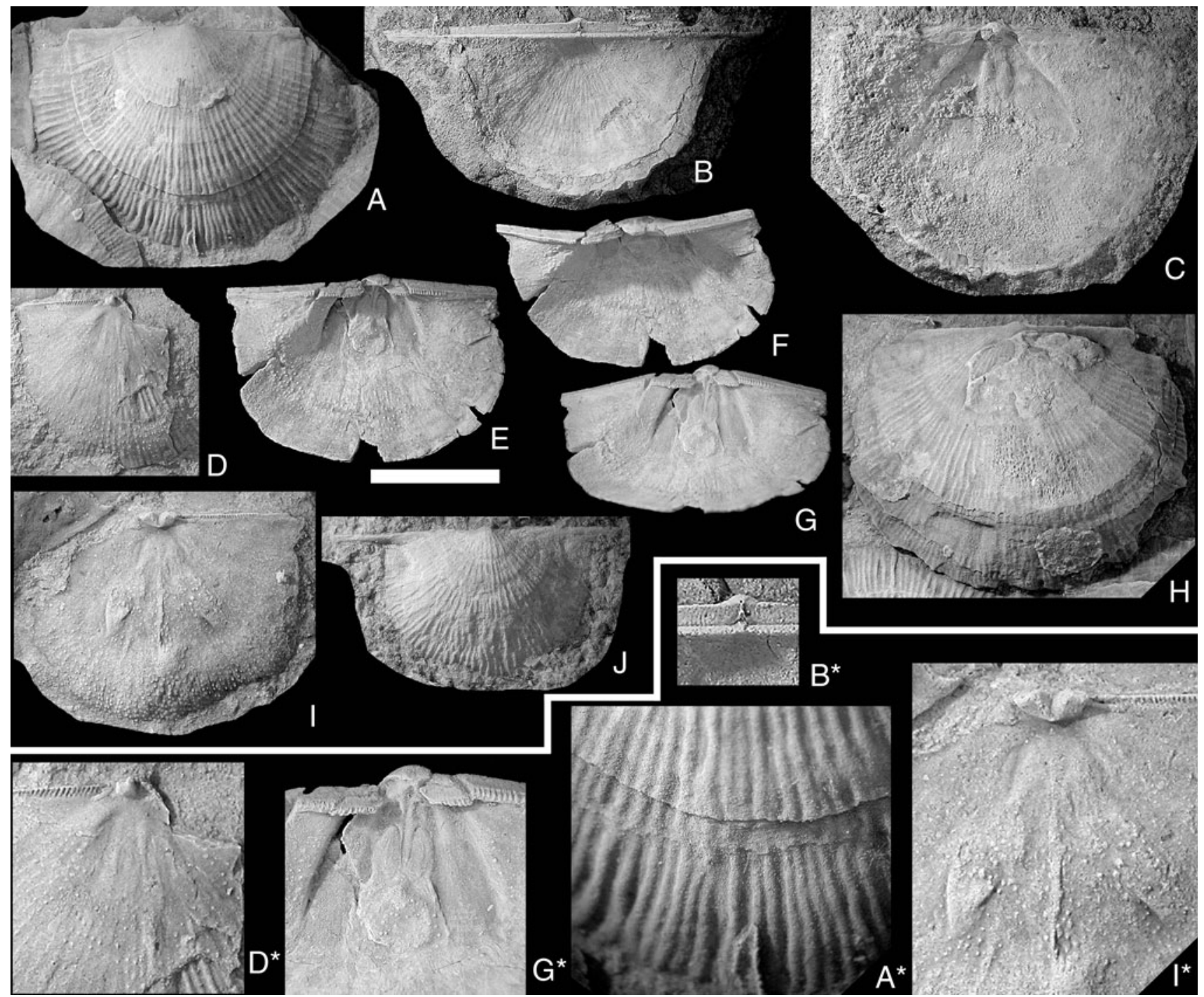

Fig. 11 Strophodonta (Strophodonta) hoburgensis n. sp. Scale bar $1 \mathrm{~cm}$, except in figures $\mathbf{B}^{*}, \mathbf{D}^{*}, \mathbf{G}^{*}, \mathbf{I}^{*}=0.5 \mathrm{~cm}, \mathbf{A}^{*}=0.33 \mathrm{~cm}$. Specimens $\mathbf{A}, \mathbf{D}, \mathbf{H}, \mathbf{I}$ are from a single bedding plane in the Hamra Fm., Hoburgen, Sundre; A, A* NRM Br102617b. Ventral exterior; B, B* NRM Br34086. Dorsal view of conjoined valves with very long alae. Note pseudodeltidium and small foramen; Hamra Fm., Vamlingbo; C NRM Br123622. Ventral interior. Note elevated adductor

slightly impressed in young specimens, almost invisible in gerontic ones, divided by a strong medial ridge, which reaches almost to the anterior margin, and subdivided by trans-muscle ridges, which in gerontic specimens widen distally into arrowhead shaped platforms. The entire inner surface is covered in relatively large, widely spaced pseudopunctae arranged in radial rows near the outer shell margin, but randomly within the muscular area. The inner surface is not strongly influenced by the exterior ornament.

Remarks: $S$. (S.) hoburgensis n. sp. differs from the type species $S$. (S.) demissa in having denticles along a smaller part of the hinge line, more parallel cardinal process lobes, scars and strong ventral process; Sundre Fm., Juves, Sundre; D, D* NRM Br102617f. small dorsal interior; E-G, G* NRM Br34144. Three views of slightly crushed ventral valve. Note elevated adductor scars; Hamra Fm., Valkmyrs kanal, Vamlingbo; H NRM Br102617c. Ventral exterior; I, I* NRM Br102617a. Dorsal interior with strong transmuscle ridges; J NRM Br138253. Ventral valve with long alae; Sundre Fm., Hallbjäns, Sundre

almost effaced dorsal muscle field, no radial ridges in the ventral diductor scars, and in having both pseudodeltidium and chilidium protruding from the interareas. This is the earliest known member of the genus (noted to range from the Pridolian to the Frasnian in Cocks and Rong 2000). Harper and Boucot (1978c, p. 36) noted the presence of a species of Strophodonta on Gotland, but their locality reference (CHG28) is untraceable, as it is not defined in their paper and is also unlike all other locality references in that publication. They cited the age to be Pridolian (the youngest beds on Gotland are late but not latest Ludlow), which suggests that their material must be from the latest 
part of the succession, and thus probably conspecific with the present species.

Distribution: From the collections of NRM and SGU, Strophodonta (Strophodonta) hoburgensis n. sp. seems to be present only in the Hamra and Sundre Formations.

Family Shaleriidae Williams, 1965

Genus Shaleria Caster, 1939

Type species: By original designation; Strophomena gilpeni Dawson, 1880, p. 341; from the Ludlow-early Devonian of Nova Scotia, Canada.

Remarks: All specimens from Gotland identified within the genus Shaleria are morphologically very similar and originate from a restricted area from beds deposited in only a few million years. Yet they exhibit subtle variations in sculpture and diductor scar shape. Similar variations have been used previously as defining characters for genera and subgenera within the group (e.g., Harper and Boucot 1978b, p. 160): The difference between Shaleria Caster, 1939 and Shaleriella Harper \& Boucot, 1978 is defined as the latter being slightly geniculate, having zig-zag rugae and lacking dorsal side septa (see Cocks and Rong 2000). Harper and Boucot (1978b) referred species with dorsal side septa but with rugae to Shaleria (Protoshaleria) (not recognized by Cocks and Rong 2000), while species without rugae and lacking side septa were referred to Shaleria (Janiomya) Havlíček, 1967, and those with two pairs of side septa to $S$. (Shaleria). Several of the specimens of Shaleriella delicata figured by Harper and Boucot (1978b, pl. 34, e.g., Figs. 15, 20,23 ) do not have rugate sculpture, and all the specimens are also small, which casts doubt upon the lack of dorsal side septa being a valid character. That leaves the geniculation as the single defining character, but Shaleria (Shaleria) honeymani McClearn, 1924 is also geniculate while having subequally costellate sculpture (Harper 1973, pl. 13, Figs. 8, 10). This shows that the differences between Shaleria and Shaleriella are too small for generic differentiation, and Shaleriella is at most a subgenus of Shaleria. The inconsistency of the characters defining the subgenera of Shaleria indicates that the genus perhaps should remain undivided into subgenera, but this would also mask the variability that after all is present and that seems to be consistent within the species groups.

The Gotland specimens show most of this variation within the small samples available. The variation in sculpture appears to correlate with depositional environment; rugae are present in specimens from the relatively low-energy environments in the Hemse Marl at Visne Myr and Hallsarve (both low in Hemse) and Lau kanal (top of the Hemse Marl), while those from the higher energy environment at Millklint (high in the Hemse Limestone) developed unequal parvicostellate or costellate sculpture without rugae.

The two dorsal interiors in the present material (Fig. 12G, $\left.G^{*}, J\right)$ show no dorsal side septa and are rugate, but one of them is associated with other apparently non-rugate valves showing diductor scars similar to those in Shaleria ornatella (see also Harper and Boucot 1978b, pl. 35, Figs. 1-10).

\section{Subgenus Shaleria (Janiomya) Havlíček, 1967 (=S. (Protoshaleria) Harper \& Boucot, 1978)}

Type species: By original designation: Janiomya parallelomya Havlíček, 1967, p. 175-176, pl. 36, Figs. 3-5; from the Budňanian (Ludlow- Přídolí) of Bohemia, Czech Republic.

Remarks: $S$ (Protoshaleria) was synonomized with Shaleria (Shaleria) by Cocks and Rong (2000), but the undivided shape of the ventral diductor scars and the single pair of small dorsal side septa make the species referred to this subgenus by Harper and Boucot (1978b, p. 163) more similar to the type species of $S$. (Janiomya) than to S. gilpeni, which has a strong second pair of diductor scars and two pairs of long dorsal side septa.

Shaleria (Janiomya) ornatella (Davidson, 1871) (Fig. 12A-L)

v*1871 Strophomena ornatella—Davidson: $309, \mathrm{pl} .43$, Figs. 16-20

v.1902 Strophomena impressa Lindström.-Munthe: 233-234, Figs. 3-4

v.1921 Leptostrophia impressa (Lindström).—Hede: 92 [name only]

v.1925 Leptostrophia impressa (Lindström).--Hede: 48 [name only]

v.1939 Shaleria ornatella (Davidson).-Caster: 34

v.1963 Shaleria ornatella (Davidson).- - Holland et al.: 154, pl. 3, Fig. 1

v.1974 Shaleria aff. ornatella (Davidson).-Bassett \& Cocks: 17

v.1978 Shaleria ornatella (Davidson).-Cocks: 129

v.1978b Shaleria (Protoshaleria) ornatella

(Davidson).-Harper \& Boucot: 162, pl. 35, Figs. 1-10

?1985 Shaleriella tenuis-Nikiforova, Modzalevskaya \& Bassett: 23, pl. 5, Figs. 1-6

v.1994 Shaleria (Janiomya) ornatella (Davidson).Rong \& Cocks: 661, Fig. 11

v.2004 Shaleria (Shaleria) ornatella (Davidson).Musteikis \& Cocks: 466, Fig. 5L-O, 6B-H

Lectotype: Selected by Cocks 1978; GSM 13397; a pedicle valve, the original of Davidson 1871, pl. 43, 


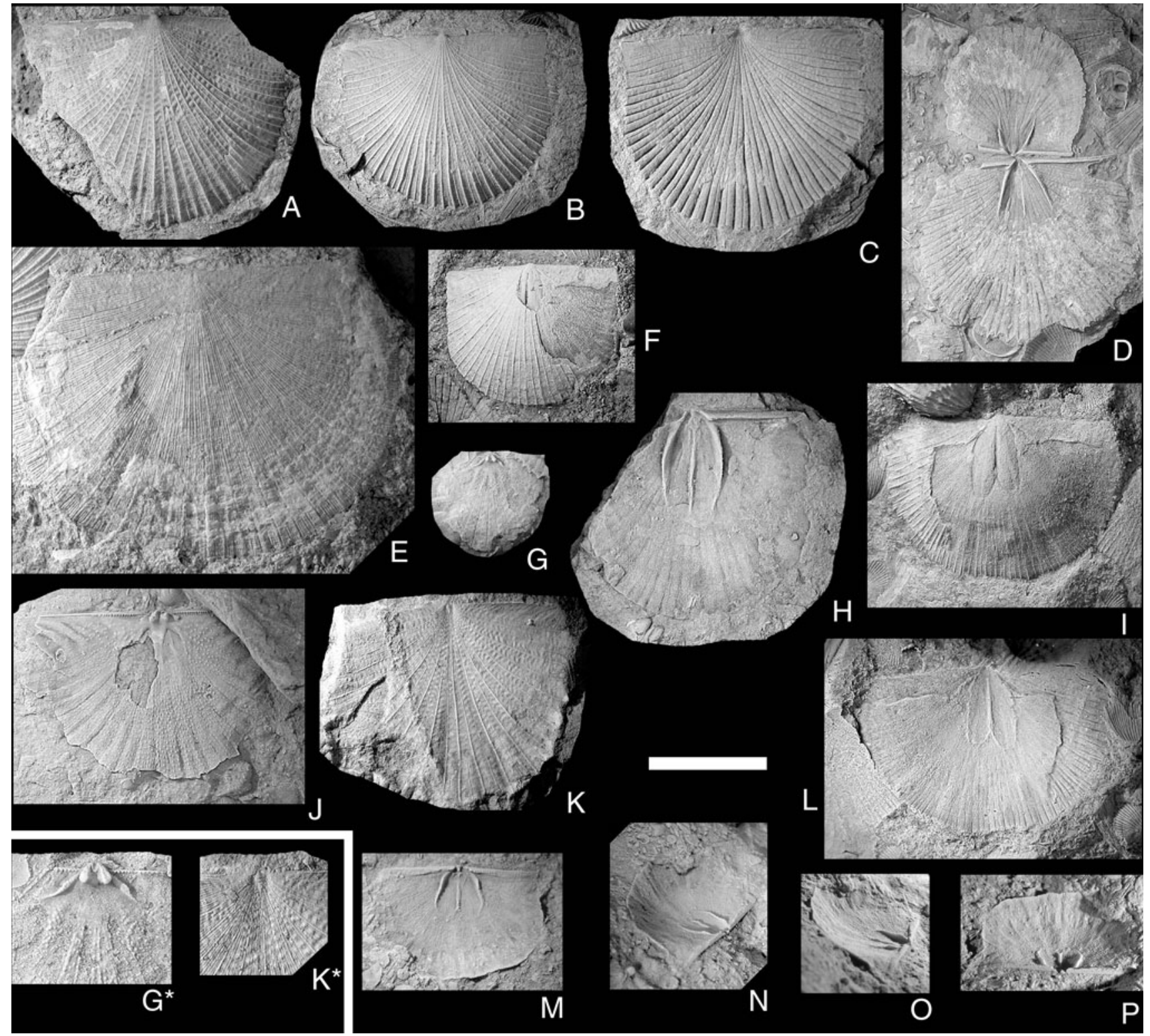

Fig. 12 A-N Shaleria (Janiomya) ornatella (Davidson, 1871). Scale bar $1 \mathrm{~cm}$, except in figures $\mathbf{G}^{*}, \mathbf{K}^{*}=0.5 \mathrm{~cm}$. A NRM Br138251. Ventral valve with strong rugae; Hemse group, Hallsarve, Lau; B, C NRM Br134453a. Latex cast and natural mold of ventral exterior with strong, unequal costellae; Hemse group, Lau kanal, Lau; D NRM Br138248a. Two ventral interiors. Note the diverging muscle bounding ridges; ?Eke Fm., Lau; E NRM Br36070a. Large ventral valve with very fine, equal costellae; Hemse group, Millklint, Ardre; F NRM Br36125d. Partly exfoliated ventral valve; Hemse group, Millklint, Ardre; G, G* NRM Br138248c. Cardinal detail and interior views of small dorsal valve; ?Eke Fm., Lau; H NRM Br138247.

Fig. 16 (top) from Upper Ludlow, Whitcliff, Ludlow, Salop, UK.

Description: Shell outline semicircular; length/width ratio about $0.70-0.85$; the widest part of the shell is usually slightly anterior to the hinge line, but the posterolateral
Ventral interior; ?Eke Fm., Lau. Note the converging muscle bounding ridges and the small size of the adductor scars; I, L NRM Br36125a. Natural mold and latex cast of ventral interior; Hemse group, Millklint, Ardre; J NRM Br130704. Interior of dorsal valve. Hemse group; Visne Myr kanal, Ardre; K, K* NRM Br134452a. Exterior view and umbonal detail of rugate dorsal valve. Note shape of dorsal umbo; Hemse group, Lau kanal, Lau; M-P Shaleria (Shaleriella) ezerensis (Rybnikova, 1966); NRM Br119540, ventral valve interior in dorsal, lateral, posterior and posterolateral views; Eke Formation, Petsarve 4, Eke. Note weak dorsal geniculation and relatively wide muscle field

corners can be produced as short alae; profile gently concavoconvex without geniculation. Ventral beak low but pronounced, slightly overhanging the interarea and bearing a small, sealed foramen at its apex; ventral interarea very narrow and apsacline to catacline; pseudodeltidium not well preserved in this material, delthyrium occupies about 
$10 \%$ of the interarea width. Dorsal beak is a small, raised knob situated slightly anterior to the hinge line; dorsal interarea not seen in this material. Ornament usually unequally parvicostellate with a variable number of smaller costellae between the stronger, more elevated primary costellae, but some specimens are multicostellate with all costellae being very thin (Fig. 12E). In some specimens (Fig. 12A), small rugae occur between the primary costellae and are deflected by them into a slight zig-zag pattern.

Delthyrial cavity shallow, most of it filled by a low ventral process, which supports the apical part of the pseudodeltidium. Proximal part of the medial process broad, but it narrows anteriorly into a thin ridge separating the diductor scars. The muscle area occupies about 30-50\% of shell length and about $20 \%$ of shell width. In most specimens, the diductor scars are surrounded by more or less parallel muscle bounding ridges, and the anterior ends are distinct, but in some specimens the ridges diverge at about $25^{\circ}$ to one another, and the anterior ends of the muscle scars are diffuse. The hinge line bears denticles on about $33 \%$ of its width; small teeth with crenulations are present in some specimens, but most are damaged in this area; teeth supported by dental plates, but these are separate from the muscle bounding ridges. Adductor scars very faint, only visible as shallow crescentic depressions at the anterior margin of the broad ventral process. Extra-muscular area covered by relatively large and dispersed pseudopunctae; the interior is strongly impressed by the exterior sculpture.

Only two specimens from Gotland were sufficiently well preserved to show details in the dorsal valve interior: The cardinalia are relatively small but stout, and elevated on a very low platform; cardinal process lobes united for $50 \%$ of their height, with narrow attachment faces directed posteroventrally, diverging at about $50^{\circ}$ from one another. Socket ridges strong, curving antero-laterally; hinge line bears denticles complementary to those of the ventral valve. Muscle scars indicated faintly by two pairs of short, low ridges originating from the anterior margin of the cardinal platform; these ridges bear larger pseudopunctae than the rest of the valve surface; the interior is strongly impressed by the exterior sculpture

Remarks: The specimens with divergent muscle bounding ridges and diffuse anterior muscle scar margins could be mistaken for specimens of Leptostrophia, but in that genus the entire hinge line is denticulate and there are no teeth. The specimens referred previously to Shaleria impressa (see Munthe 1902, Figs. 3, 4) are here referred to $S$. ornatella. The specimens from Millklint (Hemse Limestone) are somewhat different from the specimens from Lau kanal (Hemse Marl) in having a more transverse outline. They also have narrower interspaces between the primary costellae and corresponding smaller number of smaller costellae within them. No rugae are found in the Millklint specimens, and one specimen is multicostellate rather than unequally parvicostellate. In my opinion, these differences are environmentally related, since the environment at Millklint apparently was a higher energy setting. Musteikis and Cocks (2004) regarded the Podolian specimens described as Shaleriella tenuis by Nikiforova et al. (1985) as belonging to Shaleria ornatella, but this is uncertain. The Podolian material differs from British and Gotland specimens in having more denticles on the hinge line, a much more elongate outline and clearly geniculate profile. It also differs from the British material figured by Musteikis and Cocks (2004, Fig. 5L-O) in having weaker, unequally parvicostellate sculpture, but as discussed earlier, the sculpture of shaleriids seems to be strongly influenced by the environment and cannot be used for taxonomic purposes. The ridges along the dorsal muscle field are much more strongly developed in the Podolian (Nikiforova et al. 1985, pl. 5, Figs. 5-6) and Latvian material (Musteikis and Cocks 2004, Fig. 6F-H) than in the few dorsal interiors of S. ornatella figured previously from the UK and Gotland (Davidson 1871, pl. 43, Fig. 18; Harper and Boucot 1978b, pl. 35, Fig. 1b; Musteikis and Cocks 2004, Fig. 5M; and herein Fig. 12G, G*, J), although this may well be a function of ontogenetic development.

Distribution: The specimens in the collections of NRM are from the Hemse group in three different areas; one group is from a low level within the Hemse group at Millklint, Ardre parish; another group is from a low level in the Hemse group at near Fardhem Church; the third group originate from probably just below the Hemse-Eke boundary south of Lau church. Bassett and Cocks (1974) recorded the species from the Hemse, Eke and Burgsvik beds, and specimens in the collections at SGU show a range from the Hemse group and through to the Sundre Formation. The SGU collections show $S$. $(J$.) ornatella to be especially widespread in the Burgsvik Formation. In the British Isles, it is known only from the Upper Ludlow rocks of the Ludlow District, Shropshire (Holland et al. 1963).

Remarks on ecology: Hede (1925, p. 37-45) recorded this species (as L. impressa) at Lau kanal, Hallsarve, and Lau Backar, where he notes that it occurs from the upper Hemse group and into the Eke Formation, and that it is extremely abundant in a thin layer at the top of the Hemse group. From his profile descriptions, the species appears to be most common in relatively shallow water, sandy environments; in the same area, the top of the Hemse group is marked by submarine hardground horizons and quite deep erosion, while the overlying Eke Formation represents high-energy environments within normal wave base 
(Cherns 1982, 1983). Calef and Hancock (1974) record Shaleria as a moderately common constituent of the Ludlow Isorthis community, and in Wales it is confined to that community. According to these authors, this community corresponds approximately to the Llandovery Stricklandia community of Ziegler et al. (1968) and is typical of relatively offshore environments. Harper and Boucot (1978c, p. 10) on the other hand, state that shaleriids are typical of Benthic Assemblage 2, which has been interpreted as subtidal (Boucot 1975). The Gotland shaleriid material supports the latter interpretation in that they occur in apparently shallow water sediments, especially at Lau backar, where other brachiopods [e.g., Lepidoleptaena poulseni (Kelly, 1967)] are often coated with oncolithic crusts deposited by algae (see Hoel 2005, Fig. 8).

\section{Subgenus Shaleria (Shaleriella) Harper \& Boucot, 1978}

Type species: By original designation: Shaleriella delicata n. sp. Harper \& Boucot 1978b, p. 160-161, pl. 34, Figs. 11-25, 29, from the late Ludlow Hemse group and Eke Formation of Gotland [subjective synonym of Shaleria (Shaleriella) ezerensis (Rybnikova, 1966) from the Přídolían Jūra Formation of Latvia, see Musteikis and Cocks, p. 468].

Remarks: As discussed above, the diagnostic features of Shaleriella are not sufficiently specific to warrant generic status, but the variation is considered too wide to allow Shaleria to remain undivided into subgenera.

Shaleria (Shaleriella) ezerensis (Rybnikova, 1966) (Fig. 12M-P)

v*1966 Brachyprion ezerensis-Rybnikova: 80, pl. 1, Figs. 9, 10

v.1967 Brachyprion ezerensis Rybnikova.-Rybnikova: 193, pl. 21, Figs. 1, 2

v.1978 Shaleriella delicata n. sp.--Harper \& Boucot: 161, pl. 34, Figs. 11-25, 29

v.2000 Shaleriella delicata Harper \& Boucot.-Cocks \& Rong: 302, Fig. 192: 2a-c

v.2004 Shaleria (Shaleriella) ezerensis (Rybnikova).Musteikis \& Cocks: 468, Figs. 5P, 6A, I-P

Holotype: LMNH Br.30/12, a ventral exterior from the Přidoli Jüra Formation, at the 926.8-m level in the Ezere borehole, Latvia. Refigured by Musteikis and Cocks (2004, Fig. 6I) (Holotype of S. delicata: By original designation: USNM 220911; a, from Hemse marl (at Gogs, Lau parish, Gotland), figured by Harper and Boucot 1978b, pl. 34, Fig. 17.)

Description of the specimen (NRM Br119540): Delthyrial cavity shallow, mostly filled by a low ventral process, which supports the apical part of the pseudodeltidium; this medial process is raised on a platform posteriorly; anterior margin of the platform excavated to form two small depressions flanking the anterior projection of the ventral process. The hinge line bears denticles only a short distance laterally from the delthyrium; no dental plates present. Muscle field elongate, diductor scars subparallel with rounded anterior margins; lateral bounding ridges high posteriorly, very low but visible anteriorly; adductor scars short and narrow, posteriorly placed; extramuscular area covered in large, radially arranged taleolae; no vascular traces visible.

Remarks: Only a single specimen with the geniculate profile supposedly characteristic for this species was found in the collections of NRM. It is from Petsarve 4, which is in a high level within the Eke Formation, while all other shaleriid specimens in the collections of NRM originate from the uppermost Hemse group or lower Eke Formation and are not geniculate. A specimen found by me in a sandstone from the upper part of the Burgsvik Formation is identical to the NRM specimen, other than lacking geniculation. Strangely enough the specimens figured by Musteikis and Cocks (2004, Figs. 5P, 6A) as S. ezerensis from the Hemse group at Millklint are apparently not geniculate. They are similar to the specimens figured as S. ornatella herein from Millklint (Fig. 12E, I, L). The holotype of $S$. ezerensis, as well as the other Latvian specimens figured by Musteikis and Cocks (2004), have much stronger geniculation than the Gotland specimens figured as S. delicata by Harper and Boucot 1978b, to the point that they display a fold-and-sulcus, of which there is no trace in the Gotland specimens.

Distribution: Harper and Boucot (1978b, p. 161) recorded this species (as $S$. delicata) from the upper part of the Slite group very close to the Bara Oolite, the middle part of the Hemse Group near Linde klint, upper part of the Hemse group and lower Eke Formation near and on the Eke outliers of Lau backar and Burgen in the east, and near Eke church in the west, and high in the Eke marl at Ronehamn. The latter locality is very near the locality and stratigraphic level of the specimen figured herein. I have also found specimens of this species near the boundary between the Burgsvik and Hamra formations at Kättelviken. All these localities were in high-energy environments.

Ecological remarks

The study of leptaenines on Gotland (see Hoel 2005, 2008) revealed a morphological trend linked to the depositional environment, especially the water energy: Specimens found in low-energy environments have subdued concentric ornament and closed apical foramina, whereas those from 
higher energy environments have strong concentric ornament and open apical foramina. In all three genera studied herein there are comparable morphological trends: In the Visby beds, the specimens of Pentlandina tartana have regular shape, weak ornament and usually a small, open pedicle foramen (Fig. 4); in the Högklint beds, specimens of $P$. loveni are irregular, with stronger concentric ornament, and large pedicle foramen. In the Slite beds, the specimens of $P$. lewisii (Fig. 5W-Af) have no pedicle foramen and mostly only radial ornament (as in Leptaena depressa, see Hoel 2005). The single specimen of $P$. cf. lewisii (Fig. 5U, V) from the Klinteberg Formation presumably is phylogenetically closer to $P$. lewisii, but is morphologically quite similar to $P$. loveni in having a strong concentric ornament and large pedicle foramen. A similar influence on shape and ornament is seen in Katastrophomena, where the low-energy environments of the Visby Formation contains $K$. penkillensis with triangular shell outline, thin shells and ornament of thin, widely spaced costellae and very fine rugae (Fig. 6A, G), whereas the slightly higher energy environments of the Hemse group contain $K$. antiquata scabrosa with semi-circular outline, thick shells and strong, closely spaced, gnarly costellae (e.g., Fig. 7A, E). Similar strong ornament is also seen in specimens of $K$. penkillensis in the high energy environment of the Högklint Formation (Fig. 6J). In Bellimurina wisgoriensis the environmental influence on morphology is seen within a single species between specimens from the Visby Formation (with subtly expressed costellae and rugae, and geniculation) and from reefs of the Högklint Formation (with strong ornament, frilly growth lamellae and a much stronger development of the anterior fold-and-sulcus). In higher energy environments Bellimurina wisgoriensis and Pentlandina loveni both develop strong, diamond-shaped shell ornament by the interplay of costellae and rugae and a more pronounced irregularity of overall shell shape than their low-energy environment counterparts. The morphological response to environmental changes is thus quite similar in all three genera.

In contrast to the morphological plasticity in response to environmental factors seen in the Leptaenines and furcitellinines, all of the "strophodontids" described in the present paper display only minute variability, and this cannot be related to differences in environment. Three of the species [the strophodontide Strophodonta hoburgensis n. sp. and the shaleriids Shaleria (Janiomya) ornatella and S. (Shaleriella) ezerensis] have short ranges and occur only in high-energy environments, while the leptostrophiide Brachyprion (Erinostrophia) walmstedti is likewise short ranged, occurring only in the low-energy Visby Formation. Another "strophodontide" with similar narrow temporal and ecological ranges are Mesopholidostrophia laevigata, which is confined to the low-energy Mulde marl of the Halla Formation.

The other "strophodontids" on Gotland have long ranges and wide environmental tolerances; Mesoleptostrophia filosa and Brachyprion (Brachyprion) semiglobosa occur in both high- and low-energy environments without any marked morphological variation, neither due to environment or micro-evolution. M. filosa was also recognized as having a very wide environmental tolerance by Calef and Hancock (1974), who noted that the species occur in every brachiopod community recognized in the Wenlock and Ludlow of Britain, from inshore to deep water. Apparently the moderately concavo-convex shell profile and subdued shell ornament were a very successful adaptation evolved many times in many different lineages. Similar morphology and distribution are also found in Strophonella euglypha, Amphistrophiella funiculata and the chilidiopside Coolinia.

Acknowledgments This work was carried out at the Department of Geosciences, Palaeobiology Program, Uppsala University, as part of my Ph.D. project. I am grateful to Professor Michael Bassett, Cardiff, for initiating the project on Gotland Strophomenides and for many helpful comments on the manuscript, and to Professor Lars Holmer, Uppsala, for help throughout this work. Photographic assistance and comments were provided by Dr. Jan Ove Ebbestad and Dr. Christian Skovsted, Uppsala. Christina Franzén Bengtsson (NRM) and Lars Karis (Swedish Geological Survey, Uppsala) kindly made the large collections of their institutions available for study.

Open Access This article is distributed under the terms of the Creative Commons Attribution Noncommercial License which permits any noncommercial use, distribution, and reproduction in any medium, provided the original author(s) and source are credited.

\section{References}

Baarli, B.G. 1995. Orthacean and strophomenid brachiopods from the Lower Silurian of the central Oslo Region. Fossils and Strata 39: $1-93$.

Bancroft, B.B. 1949. Welsh Valentian brachiopods and the Strophomena antiquata group of fossil brachiopods, ed. A. Lamont, Privately printed. 16 pp., 3 pls. Mexborough.

Bassett, M.G. 1971. Wenlock Stropheodontidae (Silurian Brachiopoda) from the Welsh Borderland and south Wales. Palaeontology 14: 303-337.

Bassett, M.G. 1974. The articulate Brachiopods from the Wenlock Series of the Welsh Borderland and South Wales. Monographs of the Palaeontographical Society. Part 3 (pp. 79-122, pls. 18-32).

Bassett, M.G. 1977. The articulate Brachiopods from the Wenlock Series of the Welsh Borderland and South Wales. Monographs of the Palaeontographical Society. Part 4 (pp. 123-176, pl. 33-47).

Bassett, M.G. 1985. Silurian stratigraphy and facies development in Scandinavia. In The Caledonide Orogen Scandinavia and related areas, ed. D.G. Gee, and B.A. Sturt, 283-292. London: Wiley.

Bassett, M.G.B. and Rong J.-Y. 2002. Brachiopods. In: Telychian rocks of the British Isles and China (Silurian, Llandovery 
Series), eds. Holland, C.H. and Bassett, M.G.B., National Museums and Galleries of Wales, Geological Series 21: 124-136.

Bassett, M.G.B. and Cocks, L.R.M. 1974. A review of Silurian brachiopods from Gotland. Fossils and Strata 3: 1-56, pl. 1-11.

Billings, E. 1860. Description of some new fossils from the lower and middle Silurian rocks of Canada. Canadian Naturalist 5(3): 49-69.

Boucot, A.J. 1975. Evolution and extinction rate controls. Developments in Paleontology and stratigraphy 1, 423 p. Elsevier Publishing Co.

Calef, C.E., and N.J. Hancock. 1974. Wenlock and Ludlow marine communities in Wales and the Welsh Borderlands. Palaeontology 17: 779-810.

Caster, K.E. 1939. A Devonian fauna from Colombia. Bulletin of American Paleontology 24: 1-218, pl. 1-14.

Cherns, L. 1982. Palaeokarst, tidal erosion surfaces and stromatolites in the Silurian Eke formation of Gotland, Sweden. Sedimentology 29: 819-833.

Cherns, L. 1983. The Hemse-Eke Boundary. Facies relationships in the Ludlow Series of Gotland, Sweden. Sveriges Geologiska Undersökning C 800: $44 \mathrm{p}$.

Cocks, L.R.M. 1968. Some strophomenacean brachiopods from the British Lower Silurian. British Museum (Natural History), Bulletin (Geology) 15(6): 283-324.

Cocks, L.R.M. 1978. A review of British Lower Palaeozoic brachiopods, including a synoptic revision of Davidson's monograph. London: Monographs of the Palaeontographical Society. 256 p.

Cocks, L.R.M., and J.-Y. Rong. 2000. Strophomenida. In Treatise on Invertebrate Paleontology. Part H: Brachiopoda (Revised), Vol 2-3, ed. A. Williams, C.H.C. Brunton, and S.J. Carlson, 216-348. Boulder, CO: University of Kansas.

Cocks, L.R.M., and D. Worsley. 1993. Late Llandovery and early Wenlock stratigraphy and ecology in the Oslo Region, Norway. Bulletin of The Natural History Museum (Geology) 49(1): 31-46.

Conrad, T.A. 1842. Observations on the Silurian and Devonian systems of the United States, with descriptions of new organic remains. Journal of the Academy of Natural Sciences Philadelphia 8: 228-280.

Cooper, G.A. 1956. Chazyan and related brachiopods. Smithsonian miscellaneous Collections 127 (1): 1-1024, (2): 1025-1245, pl. $1-269$.

Davidson, T. 1847. Observations on some of the Wenlock-limestone Brachiopoda, with descriptions of several new species. London Geological Journal 1: 52-65, pl. 12-13.

Davidson, T. 1848. Mémoire sur les Brachiopodes du Système Silurien supérieur de l'Angleterre. Société Géologique de France, Bulletin (series 2) 5:309-338, 370-374, 2 pl.

Davidson, T. 1866-1871. A monograph of the British fossil Brachiopoda. Vol. 3, Part 7, Silurian. Palaeontographical Society [Monograph]: No. 1, 1866, 1-88, Pls. 1-12; No. 2, 1867, 89-168, Pls. 13-22; No. 3, 1869, 169-248, Pls. 23-37; No. 4, 1871, 249-397, Pls. 38-50.

Davidson, T. 1883. A Monograph of the British Fossil Brachiopoda, Vol. 5. Silurian Supplement, part 2. Palaeontographical Society Monograph. 135-242, pl. 8-17. London.

Dawson, J.W. 1880. New facts respecting the geological relations and fossil remains of the Silurian iron-ores of Pictou, Nova Scotia. Canadian Naturalist and Geologist (new series) 9: 332-344.

Dewing, K. 1999. Late Ordovician and Early Silurian strophomenid brachiopods of Anticosti Island, Québec, Canada. Palaeontographica Canadiana 17: 143 pp.

de Verneuil, E. 1848. Notes sur quelques brachiopodes de l'ile de Gotland. Bulletin de Societé Géologique de France (2) 5: 339-347, pl. 4.
Hall, J. 1850. On the Brachiopoda of the Silurian Period. Proceedings of the American Association for the Advancement of Science 2: 247-351.

Hall, J. and Clarke, J.M. 1892-1895. An introduction to the study of the genera of Paleozoic Brachiopoda. New York Geological Survey, Paleontology of New York 8:1: 1-367, pls. 1-20 [1892]; 8:2: 1-317 [1893]; 8:2: 319-394, pls. 21-84 [1895].

Harper, C.W. 1973. Brachiopods of the Arisaig Group (SilurianLower Devonian) of Nova Scotia. Geological Survey of Canada Bulletin 215: 163 pp., 3 figs, 28 pls. Ottawa.

Harper, C.W. Jr. and Boucot, A.J. 1978a. The Stropheodontacea, part I. Palaeontographica (A) 161: 55-118, pl. 1-18.

Harper, C.W. Jr. and Boucot, A.J. 1978b. The Stropheodontacea, part II. Palaeontographica (A) 161: 119-175, pl. 19-35.

Harper, C.W. Jr. and Boucot, A.J. 1978c. The Stropheodontacea, part III. Palaeontographica (A) 162: 1-80, pl. 36-50.

Havlíček, V. 1967. Brachiopoda of the suborder Strophomenidina in Czechoslovakia. Rozpravy Ústrenıho ústavu geologického 33: 235 p, 52 pls. Praha.

Hede, J.E. 1921. Gottlands Silurstratigrafi. Sveriges Geologiska Undersökning C 305: 1-100.

Hede, J.E. 1925. Berggrunden (Silursystemet). In Munthe, H., Hede, J.E. and von Post, L., Kartbladet R.. Sveriges Geologiska Undersökning Aa, Vol. 156, pp. 14-51.

Hede, J.E. 1960. The Silurian of Gotland. In Regnéll, G. and Hede, J.E., The lower Palaeozoic of Scania and the Silurian of Gotland. 21st International Geological Congress; Guide to excursions A22 and C17: 44-89. Sveriges Geologiska Undersökning.

Hoel, O.A. 2005. Silurian Leptaeninae (Brachiopoda) from Gotland, Sweden. Paläontologische Zeitschrift 79(2): 263-284.

Hoel, O.A. 2007. Cementing strophomenide brachiopods from the Silurian of Gotland (Sweden): Morphology and life habits. Geobios 40: 589-608.

Hoel, O.A. 2008. Evidence for muscular control of the apical pedicle in a Silurian Leptaenine brachiopod from, Gotland, Sweden, and its life position. Fossils and Strata 54: 53-58.

Holland, C.H., Lawson, J.D. and Walmsley, V.G. 1963. The Silurian rocks of the Ludlow district, Shropshire. Bulletin of British Museum of Natural History (Geology) 8: 93-171, pls. 1-7.

Holtedahl, O. 1916. The Strophomenidae of the Kristiania Region. Det Norske Vitenskaps-Akademi i Oslo. I. Skrifter. MatematiskNaturvitenskapelig Klasse 1915 (No. 12): 1-117, pl. 1-16.

Kelly, F.B. 1967. Silurian Leptaenids (Brachiopoda). Palaeontology 10(4): $590-602$.

King, W. 1846. Remarks on certain genera belonging to the class Palliobranchiata. Annals and Magazine of Natural History (series 1) 18: 26-42, 83-94.

La Touche, J.D. 1884. A Handbook of the Geology of Shropshire. 91 pp., 22 pls. London and Shrewsbury.

Lamont, A. and Gilbert, D.L.F. 1945. Upper Llandovery brachiopoda from Coneygore Coppice and Old Storridge Common, near Alfrick, Worcestershire. Annual Magazine of Natural History (11) 12: 641-682, pl. 3-7.

Laufeld, S. 1974. Silurian Chitinozoa from Gotland. Fossils and Strata 5: 1-130.

Laufeld, S., and M.G.B. Bassett. 1981. Gotland: The anatomy of a Silurian carbonate platform. Episodes 1981(2): 23-27.

Lindström, G. 1861. Bidrag till kännedomen om Gotlands brachiopoder. Öfversikt af Kungliga Vetenskapsakademiens Förhandlingar Stockholm 17 [för 1860]: 337-382, pl. 12-13.

M'Coy, F. 1846. A synopsis of the Silurian fossils of Ireland collected from the several districts by Richard Griffith, F.G.S. 72 p, 5 pls., Dublin.

Manten, A.A. 1971. Silurian reefs of Gotland. Developments in Sedimentology 13: 539 p. Amsterdam (Elsevier). 
McClearn, F.H. 1924. Paleontology of the Silurian Rocks of Arisaig, Nova Scotia. Geological Survey of Canada Memoir 137: 1-179, 30 pls.

Munthe, H. 1902. Stratigrafiska studier öfver Gotlands Silurlager 192: 55 p. Sveriges Geologiska Undersökning C 192: 55p. Also in: Geologiska Föreningen i Stockholms Förhandlingar 24(4): 221-273.

Munthe, H., Hede, J.E. and von Post, L. 1925. Gottlands Geologi. En översikt. Sveriges Geologiska Undersökning C 331: 130 p.

Murchison, R.I. 1839. The Silurian System. Founded on geological researches in the counties of Salop, Hereford, Radnor, Montgomery, Caermarthen, Pembroke, Monmouth, Gloucester, Worcester, and Stafford; with descriptions of the coalfields and overlying formations. i-xxxii, 768 p., 37 pls., London.

Musteikis, P., and L.R.M. Cocks. 2004. Strophomenide and orthotetide Silurian brachiopods from the Baltic region, with particular reference to Lithuanian boreholes. Acta Palaeontologica Polonica 49(3): 455-482.

Nikiforova, O.I., Modzalevskaya, T.L. and Bassett, M.G. 1985. Review of the upper Silurian and lower Devonian articulate brachiopods of Podolia. Special Papers in Palaeontology 34: $66 \mathrm{p}$.

Paeckelmann, W. and Sieverts, H. 1932. Ober-silurische und devonische Faunen der Prinzeninseln, Bithyniens und Thraziens. Abhandlungen der Preussischen Geolologischen Landesanstalt, Berlin (new series) 142: 1-79, 4 pls.

Pander, C.H. 1830. Beiträge zur Geognosie des Russichen Reiches. $x x+165$ p., 31 pls., St. (Gedruckt bei K. Kray): Petersburg.

Phillips, J. and Salter, J.W. 1848. Palaeontological appendix to Professor John Phillips' Memoir on the Malvern Hills compared with the Palaeozoic districts of Abberley etc. Memoirs of the Geological Survey of Great Britain, London 2(1): 331-386, pl. 4-30.

Reed, F.R.C. 1917. The Ordovician and Silurian Brachiopoda of the Girvan district. Transactions of the Royal Society of Edinburg 51: 795-998, pl. 1-24.

Richardson, J.R. 1997. Ecology of articulated brachiopods. In Treatise on Invertebrate Paleontology. Part H, Brachiopoda (Revised), Vol. 1, ed. Kaesler, R.L., 441-462, Boulder \& Lawrence (The Geological Society of America \& The University of Kansas).

Rong J.-Y. and Cocks, L.R.M. 1994. True Strophomena and a revision of the classification and evolution of strophomenoid and "strophodontoid" brachiopods. Palaeontology 37: 651-694, pl. $1-7$.

Rybnikova, M.V. 1966. Some Strophomenid brachiopods from the upper Silurian rocks of Latvia [in Russian]. In Paleontologiâ $i$ stratigrafiâ Pribalitiki i Belorussii, Vol. 1, ed. Grigelius, A.A., 75-95, Vilnius (Mintis).

Rybnikova, M.V. 1967. Phylum Brachiopoda [in Russian]. In Stratigrafiâ, fauna $i$ usloviâ obrozovaniâ silurijskih porod Pribaltiki, eds. Gailite, L.K., Rybnikova, M.V. \& Ulst, R.Z., 169-221, Riga (Zinatne).
Salter, J.W. In: Murchison, R.I. 1854. Siluria. The history of the oldest known rocks containing organic remains, with a brief description of the distribution of gold over the earth. I-xvi, 1-523, pls. 1-37. London.

Samtleben, C., A. Munnecke, T. Bickert, and J. Pätzold. 1996. The Silurian of Gotland (Sweden): Facies interpretation based on stable isotopes in Brachiopod shell. Geologische Rundschau 85: 278-292.

Shaler, N.S. 1865. List of the Brachiopoda from the Island of Anticosti sent by the Museum of Comparative Zoology to different institutions in exchange for other specimens, with annotations. Bulletin of the Museum of Comparative Zoology, Harvard 1: 61-70.

Sowerby, J. de C. 1824, 1839 and 1842. In: Sowerby, J. and Sowerby, J. de C. 1812-1846. The Mineral Conchology of Great Britain; or coloured figures and descriptions of those remains of testaceous animals or shells, which have been preserved at various times and depths in the earth. 7 volumes, pl. 1-383 (1812-1822) by J. Sowerby; pl. 384-648 (1823-1846) by J. de C. Sowerby, London.

Thomsen, E. and Baarli, B.G. 1982. Brachiopods of Lower Llandovery Sælabonn and Solvik formations of the Ringerike, Asker and Oslo districts. In Field Meeting, Oslo Region 1982, ed. Worsley, D. Palaeontological Contributions of the University of Oslo, Vol 278, pp. 63-78.

Torsvik, T., M. Smethurst, J.G. Meert, R. Van der Voo, W.S. McKerrow, M.D. Brasier, B.A. Sturt, and H.J. Walderhaug. 1996. Continental break-up and collision in the Neoproterozoic and Palaeozoic; a tale of Baltica and Laurentia. Earth-Science Reviews 40(3-4): 229-258.

Williams, A. 1951. Llandovery brachiopods from Wales with special reference to the Llandovery district. Quarterly Journal of the Geological Society of London 107: 85-136, pl. 3-8.

Williams, A. 1953. North American and European Strophodontids, their morphology and systematics. Memoirs of the Geological Society of America 56: 1-67, 13 pls.

Williams, A. 1965. Suborder Strophomenidina. In Treatise on Invertebrate Paleontology. Part H, Brachiopoda, ed. Moore, R.C., 362-412. New York and Lawrence (The Geological Society of America and The University of Kansas Press).

Williams, A., C.H.C. Brunton, and S.J. Carlson. 1997. Treatise on Invertebrate Paleontology. Part H, Brachiopoda (Revised). Volume 1: Introduction. 539 p. Boulder, CO: The Geological Society of America Inc. and The University of Kansas.

Winchell, N.H., and C. Schuchert. 1892. Preliminary descriptions of new Brachiopoda from the Trenton and Hudson River Groups of Minnesota. American Geologist, Minneapolis 9: 284-294.

Worsley, D., N. Aarhus, M.G. Bassett, M.P.A. Howe, A. Mørk, and S. Olausen. 1983. The Silurian succession of the Oslo Region. Norges Geologiske Undersøkelse Bulletin 72: 1-57.

Ziegler, A.M., L.R.M. Cocks, and R.K. Bambach. 1968. The composition and structure of lower Silurian Marine communities. Lethaia 1: 1-27. 